\title{
Palynofacies and source rock potential of the ST-7H well, offshore Tano basin, Western Region, Ghana
}

\author{
D. Atta-Peters", C. A. Achaegakwo, D. Kwayisi, P. Garrey \\ Department of Earth Science, University of Ghana, P. O. Box LG 58, Legon, Accra, Ghana
}

\section{Email address:}

dattapeters@gmail.com (D. Atta-Peters), chrisach007@yahoo.com (C. Achaegakwo), dkwayisi@gmail.com (D. Kwayisi), pgarrey@yahoo.com (P. Garrey)

\section{To cite this article:}

D. Atta-Peters, C. A. Achaegakwo, D. Kwayisi, P. Garrey. Palynofacies and Source Rock Potential of the ST-7H Well, Offshore Tano Basin, Western Region, Ghana. Earth Sciences. Vol. 4, No. 1, 2015, pp. 1-20. doi: 10.11648/j.earth.20150401.11

\begin{abstract}
Samples from ST-7H well offshore Tano basin in western region of Ghana have been subjected to palynofacies, palynological and geochemical analysis. Five palynofacies associations (I - V) have been identified based on the percentage relative abundances of the sedimentary organic matter (SOM). Palynofacies type I and type IV reflects deposition in a distal dysoxic-anoxic shelf (nearshore) environment, palynofacies type II suggest distal dysoxic to anoxic shelf to deep basin environment with abundant AOM, palynofacies type III is indicative of distal dysoxic to oxic shelf (fluvio-deltaic) environment of deposition and palynofacies type $\mathrm{V}$, a mud -dominated oxic distal shelf (open marine) environment. Based on marker palynomorphs, an Aptian to Maastrichtian age, have been assigned to the sediments in the ST 7H well, with an unconformity between the Cenomanian and Campanian sediments. Geochemical data indicate that the samples from ST $7 \mathrm{H}$ well have fair to very good petroleum potential. Most of the samples, however, fall out of the hydrocarbon generating zone because of the low $(<0.10)$ Production Index (PI). Kerogen types show type II, II/III and III which are oil prone, oil-gas prone and gas prone respectively. Thermal maturity from within the well indicates immature to early mature hydrocarbons.
\end{abstract}

Keywords: Kerogen, Palynofacies, Palynology, Organic Geochemistry, Hydrocarbon, Tano Basin

\section{Introduction}

The Tano Basin is situated close to Ghana's western border with Ivory Coast and is the eastern extension of much larger Ivory Coast Basin. It is developed between the Coastal Fault System, St Paul's and Romanche Fracture Zones. The Tano Basin occupies an area of at least $3000 \mathrm{~km}^{2}$, with the onshore component estimated at about $1165 \mathrm{~km}^{2}$ [1]. The Tano structure is located approximately $39 \mathrm{~km}$ from the Ghana coast in the Gulf of Guinea and approximately $24 \mathrm{~km}$ east of the Ghana-Ivory Coast border, with a water depth in the area ranging from $91 \mathrm{~m}$ to $125 \mathrm{~m}$.

The Tano Basin began its tectonic-sedimentary life as an extensional rift basin modified by wrench tectonism. This rifting was initiated by complex movements due to the separation of the continents of South America and Africa. This was most likely initiated in the Barremian and Aptian times. It is thought that movement along a series of transform faults including faults in the Romanche Fault Zone during this continental separation led to the development of the large rift basin in the Tano area [2]. As a result of these movements, by Aptian - early Albian time, a large rift basin had developed in the Tano Basin area. This was followed in middle - late Albian times by widespread deposition of shallow marine sandstones and shales with minor limestone in the area. General evidence suggests that final separation on the continents took place in latest Albian [2]. It is speculated that, a thermal anomaly with subsequent uplift occurred at the margin of the newly created African and Brazilian continental plates in the Tano area. This uplift occurred in late Albian time and may be the plate tectonic model for the development of the Tano structural trend.

The aim of the present study is to use palynomorph assemblages to determine the geological age of sediments from the well, to integrate it with palynofacies to interpret environment of deposition and to examine the hydrocarbon potential of the sediments using geochemical data.

\section{Materials and Methods}

Sixty four (64) samples from ditch cutting samples from ST-7H well (Fig. 1) obtained from the GNPC Core Laboratory were analyzed for study using standard 
palynological processing techniques. Each sample was digested using hydrochloric (35-38\%) and hydrofluoric (40\%) acids to remove carbonates, silicates and fluorides from the sediments. The residue after centrifuging in $\mathrm{Zn} \mathrm{Br}_{2}$ was mounted on slides for light microscopy and microphotography.

The Automatic Point Scan was used to count a total of 350 particulate organic matter and palynomorphs to determine their relative abundance in percentages at each depth (Appendix 1) (Fig. 2). To identify the divisions of the studied succession in the well using palynofacies, cluster analysis (Q-mode) was performed using SPSS software and IrfanView to generate a dendogram based on the discrete grouping characteristics (relative percentages) of the objects (Fig 3).

Data for organic carbon and Rock - Eval pyrolysis was also obtained from Ghana National Petroleum Corporation (GNPC) (Appendix3) and this was used to determine the maturity and type of organic matter in the sediments and their hydrocarbon potential.

About $100 \mathrm{mg}$ of each sample was analyzed by using Rock Eval II instrument. The output from this sensor provides the peak data for the $S_{1}$ and $S_{2}$ indices. At low temperatures kept isothermally at $300{ }^{\circ} \mathrm{C}$ for 4 minutes the free hydrocarbons in the sample were volatilized and $\mathrm{S}_{1}$ measured with a Flame Ionization Detector (FID). At increasing temperatures by programmed pyrolysis in an inert helium atmosphere at 25 ${ }^{\circ} \mathrm{C} / \mathrm{min}$ to $600^{\circ} \mathrm{C}$, hydrocarbons are expelled from the kerogen itself by cracking. This peak was measured as the $S_{2}$. The temperature at which the maximum generation of cracked hydrocarbons occurred at $\mathrm{S}_{2}$ peak is termed Tmax. Tmax is a maturation parameter that is kerogen-dependent. The $\mathrm{S}_{3}$ peak which is a result of $\mathrm{CO}_{2}$ produced from the kerogen cracking and trapped between 300-390 ${ }^{\circ} \mathrm{C}$, was detected with a thermal conductivity detector (TCD).

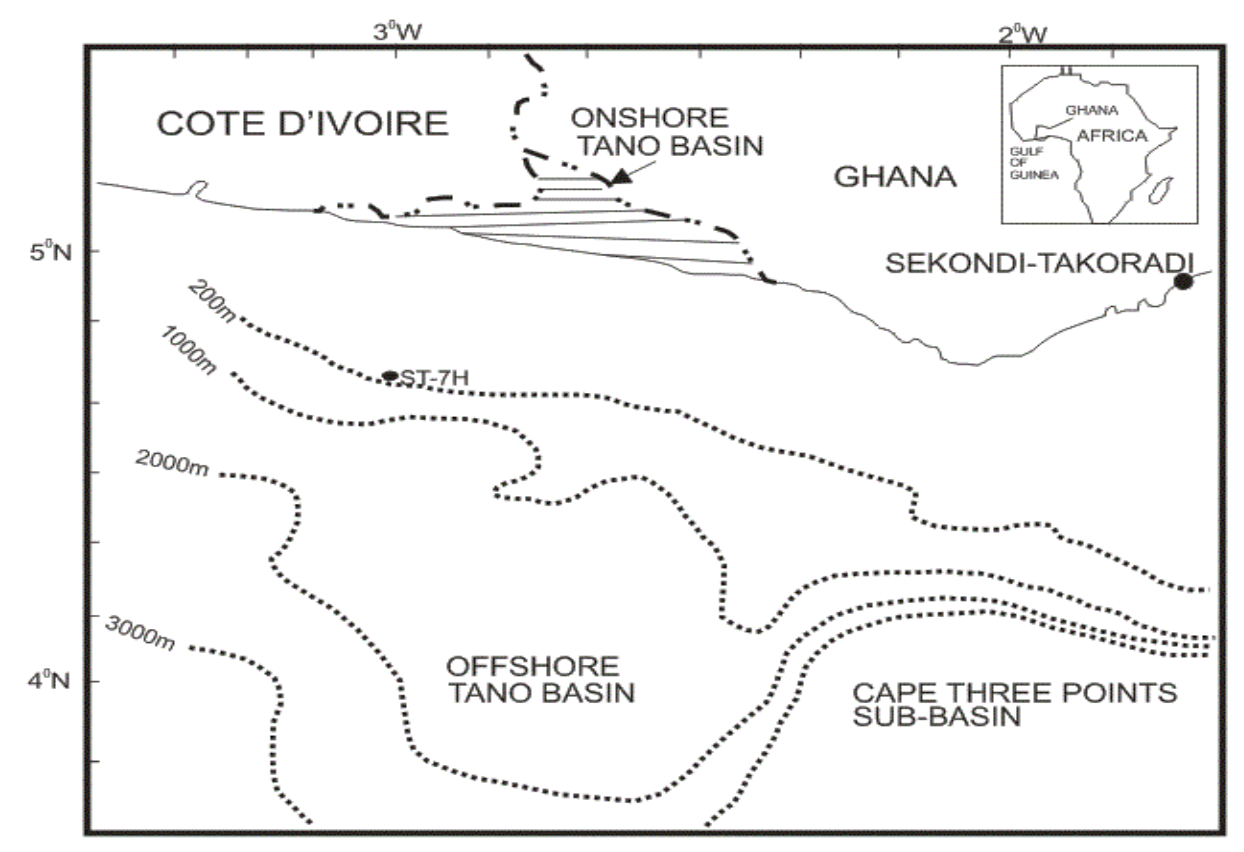

Fig 1. Map showing ST-7H well in the offshore south Tano Basin \{modified after [3]\}.

\section{Results}

\subsection{Palynofacies Analysis}

The concept of palynofacies was first introduced by [4] to describe acid-resistant organic matter in sediments. Various authors have demonstrated its usefulness in palaeoenvironmental and depositional interpretation. \{[5], [6], [7], [8], [9]\}.

The palynofacies classification terms used here follows [10]: amorphous organic matter (AOM), phytoclasts, opaque phytoclasts (black debris) and palynomorphs (spore and pollen, dinoflagellates).

- Palynomorphs include all spores, pollen, dinocysts, acritarchs, chitinozoans, microforaminiferal lining, prasinophytes, and marine algae.

- $\quad$ Phytoclasts include structured terrestrial plant fragments such as cuticles, wood tracheid and cortex tissue;

- Opaques (black debris) comprises oxidized or carbonized brownish black to black coloured woody tissues including charcoal;

- $\quad \mathrm{AOM}$ includes all particulate organic components that appear structureless at the scale of light microscopy, including bacterially-derived AOM, resinous and amorphous products of the diagenesis of macrophyte tissues.

\subsubsection{Palynofacies Types}

Cluster analysis based on the percentage and composition of kerogen elements revealed two superclusters A and B (Fig 3). Supercluster A is subdivided into four subclusters (A1, A2, A3 and A4) (Fig 3; Table 1). The AOM group dominates supercluster $\mathrm{A}$ and it is concentrated in the deeper sections of the well with the palynomorph group dominating 
supercluster B in the shallower sections of the well (Fig. 2)

\subsubsection{Palynofacies Type I (P-I). Dominance of AOM and Palynomorphs (Plate III; A, B)}

This palynofacies type is found in sample depths $5410 \mathrm{ft}$, $5490 \mathrm{ft}, 5130 \mathrm{ft}, 5590 \mathrm{ft}, 8660 \mathrm{ft}, 8580 \mathrm{ft}, 8920 \mathrm{ft}, 8120 \mathrm{ft}, 5230 \mathrm{ft}$, $7100 \mathrm{ft}, 8380 \mathrm{ft}, 8840 \mathrm{ft}, 8480 \mathrm{ft}, 8740 \mathrm{ft}, 8220 \mathrm{ft}$ and $8300 \mathrm{ft}$. It is characterized by AOM with relative abundance of $49 \%$ of total kerogen, palynomorphs $33 \%$ with opaques and phytoclasts having low relative abundance of $11 \%$ and $7 \%$ respectively (Table 2). The palynomorph group is dominated mainly by terrestrial palynomorphs contributing up to about $28 \%$ of the palynomorph group.

\subsubsection{Palynofacies Type II (P-II).AOM Dominant with Palynomorphs (Plate III; C, D)}

Palynofacies type II occurs at sample depths $6310 \mathrm{ft}$, $5050 \mathrm{ft}, 6130 \mathrm{ft}, 5850 \mathrm{ft}, 6030 \mathrm{ft}, 5770 \mathrm{ft}, 6210 \mathrm{ft}, 5690 \mathrm{ft}, 9000 \mathrm{ft}$, $6760 \mathrm{ft}, 6920 \mathrm{ft}, 6680 \mathrm{ft}, 6730 \mathrm{ft}, 6510 \mathrm{ft}, 6550 \mathrm{ft}$ and $6700 \mathrm{ft}$. It is characterized by abundant AOM with few palynomorphs, opaques and phytoclasts. Relative abundance of AOM, palynomorphs, opaques and phytoclasts are 67\%,16\%,13\% and $4 \%$ respectively (Table 2 ). The palynomorph group is dominated by terrestrial palynomorphs with little to no marine palynomorphs.

\subsubsection{Palynofacies Type III (P-III). Equal Amounts of AOM and Palynomorphs with Opaques (Plate III; E, F)}

Palynofacies type III is represented at sample depths $7150 \mathrm{ft}$, 7940ft, 7180ft, 7340ft, 7400ft, 7580ft, 6610ft and $4580 \mathrm{ft}$. Relative abundance of AOM, palynomorphs, opaques and phytoclasts are 36\%, 35\%, 20\% and 9\% respectively (Table 2). Palynofacies type III has the highest record of opaques. The palynomorphs group has nearly equal contributions from terrestrial and marine palynomorphs $(18.5 \%$ and $16.5 \%$ respectively).

\subsubsection{Palynofacies Type IV (P-IV). AOM Dominant, Palynomorphs and Opaques (Plate IV;A, B)}

Palynofacies type IV is found in sample depths $7020 \mathrm{ft}$, $7760 \mathrm{ft}, 7240 \mathrm{ft}, 6800 \mathrm{ft}, 7860 \mathrm{ft}, 6830 \mathrm{ft}, 4850 \mathrm{ft}, 6410 \mathrm{ft}, 4770 \mathrm{ft}$, $4950 \mathrm{ft}, 6470 \mathrm{ft}, 6900 \mathrm{ft}, 6970 \mathrm{ft}, 7160 \mathrm{ft}, 5050 \mathrm{ft}, 7680 \mathrm{ft}, 7400 \mathrm{ft}$, $7260 \mathrm{ft}$ and $8020 \mathrm{ft}$. High amount of AOM of relative abundance $51 \%$, palynomorphs $26 \%$, opaques $15 \%$ and phytoclasts $8 \%$ occurs in this type (Table 2). The palynomorph group is dominated by terrestrial palynomorphs with little marine palynomorphs.

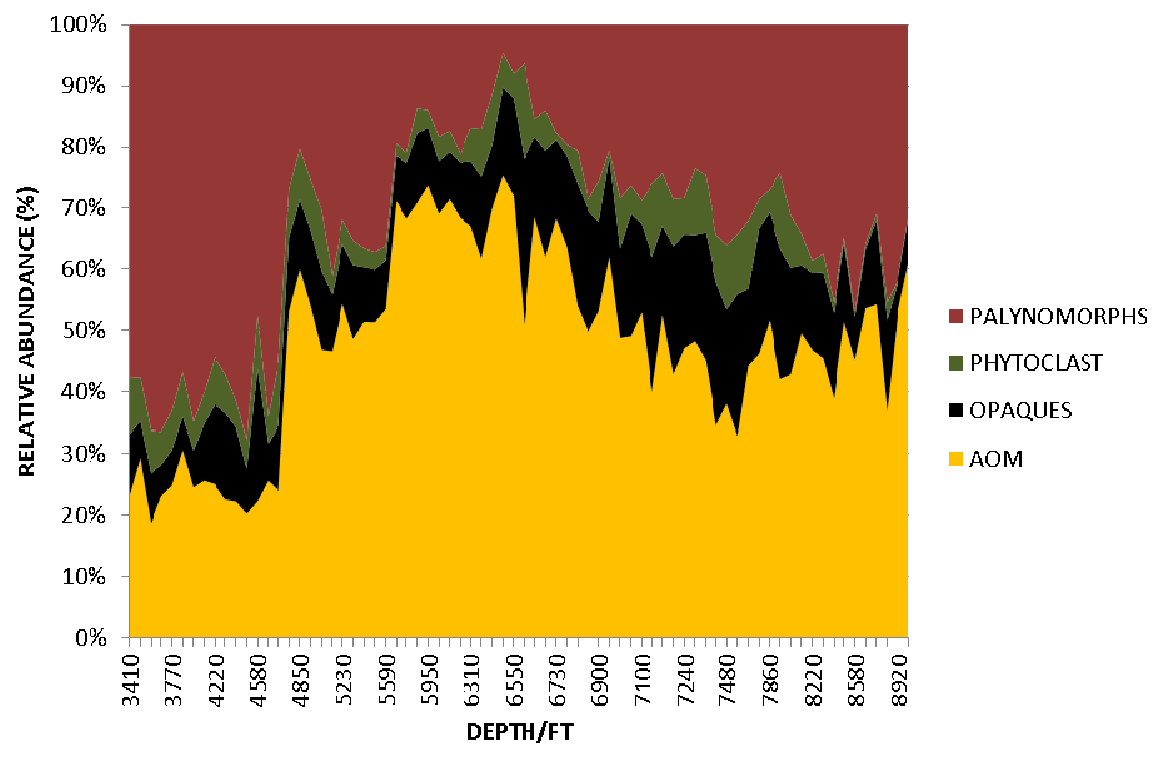

Fig. 2. Percentage relative abundances of palynomorphs, phytoclasts, opaques and AOM.

\subsubsection{Palynofacies Type V(P-V). Dominant Palynomorphs with AOM and Few opaques (Plate IV;C,D)}

This type of palynofacies is represented in sample depths $3500 \mathrm{ft}, 3860 \mathrm{ft}, 3680 \mathrm{ft}, 3950 \mathrm{ft}, 4640 \mathrm{ft}, 3770 \mathrm{ft}, 4490 \mathrm{ft}, 3590 \mathrm{ft}$, $3410 \mathrm{ft}, 4730 \mathrm{ft}, 4220 \mathrm{ft}, 4310 \mathrm{ft}, 4130 \mathrm{ft}$ and $4400 \mathrm{ft}$. It is characterized by abundant palynomorphs of relative abundance $62 \%$, AOM $19 \%$ and few amounts of opaques and phytoclasts with almost equal relative abundances of $9 \%$ and $10 \%$ respectively (Table 2). The palynomorph group is dominated by marine palynomorphs which contributes about $48 \%$ of the palynomorph group.

Table 1. Palynofacies associations identified after cluster analysis.

\begin{tabular}{lll}
\hline Palynofacies type & Description & Cluster \\
\hline P-I & Dominance of AOM and palynomorphs with few phytoclasts & A1 \\
P-II & Dominance of AOM with palynomorphs & A2 \\
P-III & Equal dominance of AOM and palynomorphs with opaques & A3 \\
P-IV & Dominance of AOM with palynomorphs and opaques & A4 \\
P-V & Dominance of palynomorphs with AOM and few opaques & B \\
\hline
\end{tabular}


Table 2. Clusters, palynofacies types and percentages relative abundance of total kerogen

\begin{tabular}{llllll}
\hline Clusters & Palynofacies types & AOM & Opaques & Phytoclasts \\
\hline A1 & P(I) & 49 & 11 & 7 & 33 \\
A2 & P(II) & 67 & 13 & 4 & 16 \\
A3 & P(III) & 36 & 20 & 9 & 35 \\
A4 & P(IV) & 51 & 15 & 8 & 26 \\
B & P(V) & 19 & 9 & 10 & 62 \\
\hline
\end{tabular}

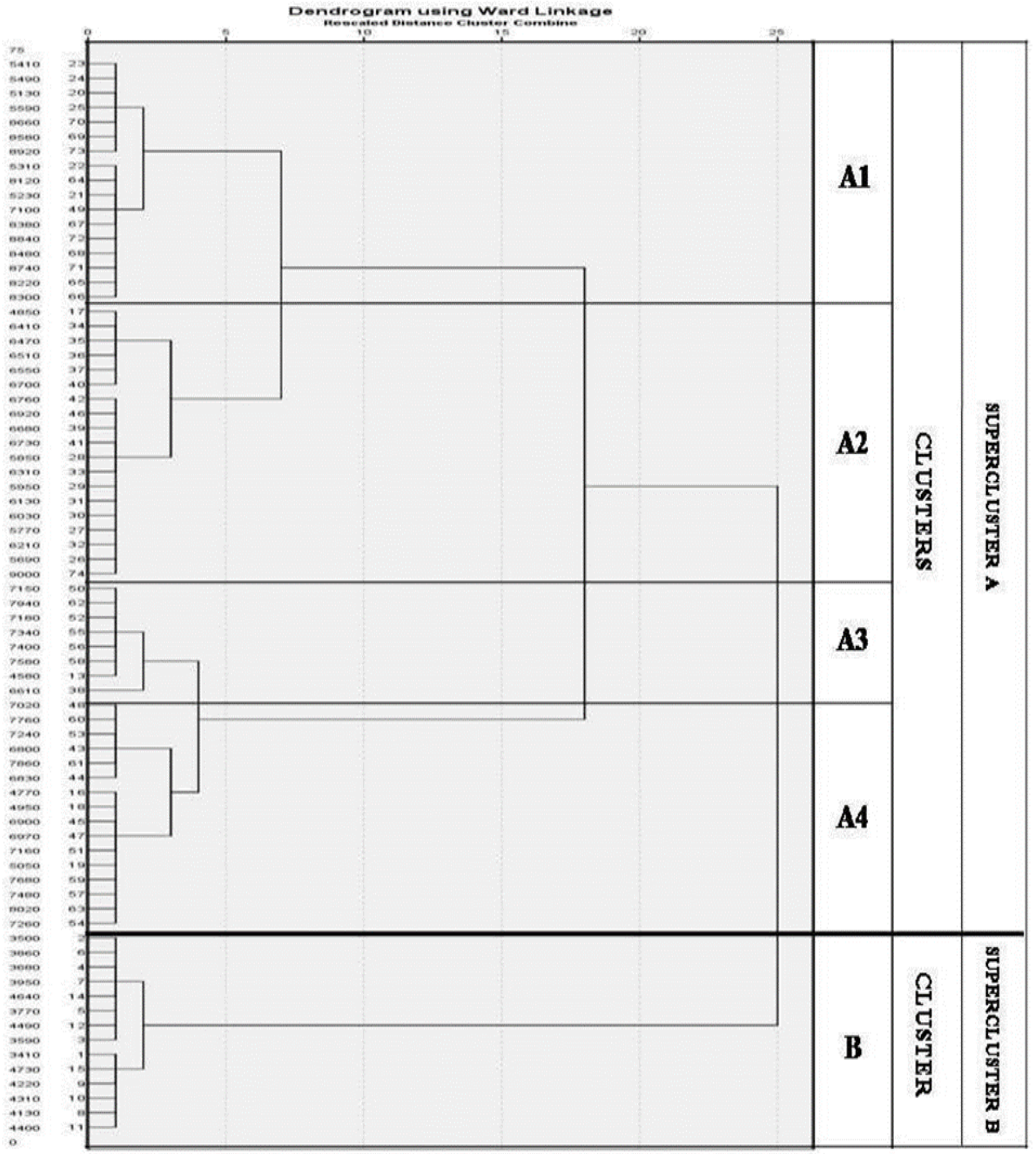

Fig. 3. Dendrogram (Q-mode) of ST-7H well shows the grouping of samples. 


\section{Discussion}

\subsection{Palynofacies and Palaeoenvironmental Analysis}

Palynological and palynofacies data retrieved from ST-7H well indicate that the samples plot within the fields V, VII, VIII and IX on the AOM - phytoclasts - palynomorphs (APP) ternary diagram (Fig. 4), representing suboxic- oxic shelf to distal shelf, distal dysoxic-anoxic shelf, distal dysoxic-oxic shelf, and distal suboxic-anoxic deep basin with abundant AOM respectively [10]

Palynofacies type I (P-I) and palynofacies type IV (P-IV) plots in field VII of Tysons APP ternary diagram which indicates deposition in a distal dysoxic-anoxic shelf condition. It is characterized by moderate to good AOM preservation, moderate abundance of palynomorphs. The palynomorph group of P-I and P-IV are dominated by terrestrial palynomorphs with little to no marine palynomorphs. [11], [12], [13], have intimated that the large amounts of AOM may be the result from a combination of high preservation rate and low energy reducing depositional environment. According to [10], [12], [14], [15], the preservation of AOM is related to dysoxic or anoxic conditions and can be, but not necessarily correlated with high primary productivity. [16] interpreted their Unit A-24 (415-383 m) based on palynofacies elements which is comparable to palynofacies P-I and P-IV of the present study as transitional (brackish lagoonal).

Palynofacies type $1(\mathrm{P}-1)$ of [17] from samples of the Neuquen Basin, Argentina is comparable to P-I and P-IV of this study. This palynofacies type is suggestive of a proximal marine environment with moderate oxidizing conditions and energy. This assemblage is comparable to Palynofacies type 5 of [18], who suggested a deltaic environment.

Palynofacies type II plots in the field IX representing a distal suboxic-anoxic deep basin which is dominated by AOM assemblages with low occurrence of palynomorphs. In oxygen-deficient basins, with high AOM preservation, allochtonous terrestrial material is dominant in the immediate vicinity of fluvio-deltaic sources or within turbidites [12], [19]. [20] reported similar palynofacies association (PF-1) from the well 16/U-1 onshore basin in eastern Yemen, and interpreted an open marine environment with the presence of the terrestrial palynomorphs indicating input from a river or transport from a nearshore environment. The palynomorphs present are mostly terrestrial palynomorphs (spores and pollen grains) with little to no marine palynomorphs.

[13] recorded high AOM (58-72\%) and common palynomorphs $(10-30 \%)$ in their Palynofacies IV, comparable to that of the present study. They contended that high AOM in organic rich sediments suggests reducing conditions and increased water column stability, resulting in dysoxic or anoxic bottom conditions. [21] reported a similar palynofacies association (PF-2) from the Jurassic basal Cretaceous Sulaiy formation, southern Iraq, and suggested a distal suboxic -anoxic basin environment for the assemblage.

Palynofacies type III (P-III) plots in the VIII field which reflects distal dysoxic-oxic shelf and has the highest percentage relative abundance of opaques (about 20\%) in the well, with almost equal percentage abundances (35\%) of AOM and palynomorphs and little phytoclasts. Relatively high percentages of terrestrial palynomorphs indicate varied and abundant vegetation associated with shoreline. [19] suggested that the high values of opaques indicate oxidizing conditions and proximity to terrestrial sources or redeposition of organic matter from fluvio-deltaic environment of deposition. The presence of relatively equal amount of AOM and palynomorphs (predominantly spores/pollen) is suggestive of a nearshore environment of deposition [18]

Palynofacies type V (P-V) plots in the field V and is indicative of a mud-dominated oxic shelf (distal shelf) and is composed of low to moderate phytoclasts and AOM. The palynomorph group is dominated by diverse marine palynomorphs (dinocysts) which contributes about $48 \%$ out of the total of $62 \%$ (Table 2). [15] inferred that their palynofacies characteristics of PF-3 and 4 with low numbers of small spores and pollen grains and much greater percentages of dinoflagellate cysts (gonyaulacoids) was an offshore environment, which is comparable with palynofacies type V (P-V).The Palynofacies Association B of [22] has a lot in common with $\mathrm{P}-\mathrm{V}$ of the study. They are both characterized by high number and diversity of dinocysts (gonyaulacoids) and other terrestrial materials which reflect a neritic or open marine environment. According to [22], depending on the type of microplankton, more specifically, gonyaulacoid dinocysts, and the ratio of sporomorphs to phytoplankton reflects the proximal-distal trends. In the palynofacies type $\mathrm{V}(\mathrm{P}-\mathrm{V})$, the microplankton (dinocysts) (Appendix 2) dominates the palynomorphs and may be indicative of a distal shelf.

[23] examined samples from Western Southland, New Zealand and suggested an inner-shelf environment of deposition to samples characterized by high proportion of mostly well preserved dinoflagellates and a low abundance of land-derived palynomorphs. [18] examined samples from northeastern Tierra del Fuego, Argentina and suggested that their palynofacies type 6 with relative abundance (56-93\%) and high diversity of marine organic-walled phytoplankton (gonyaulacoid) as having open marine neritic to outer neritic conditions of environment of deposition. 


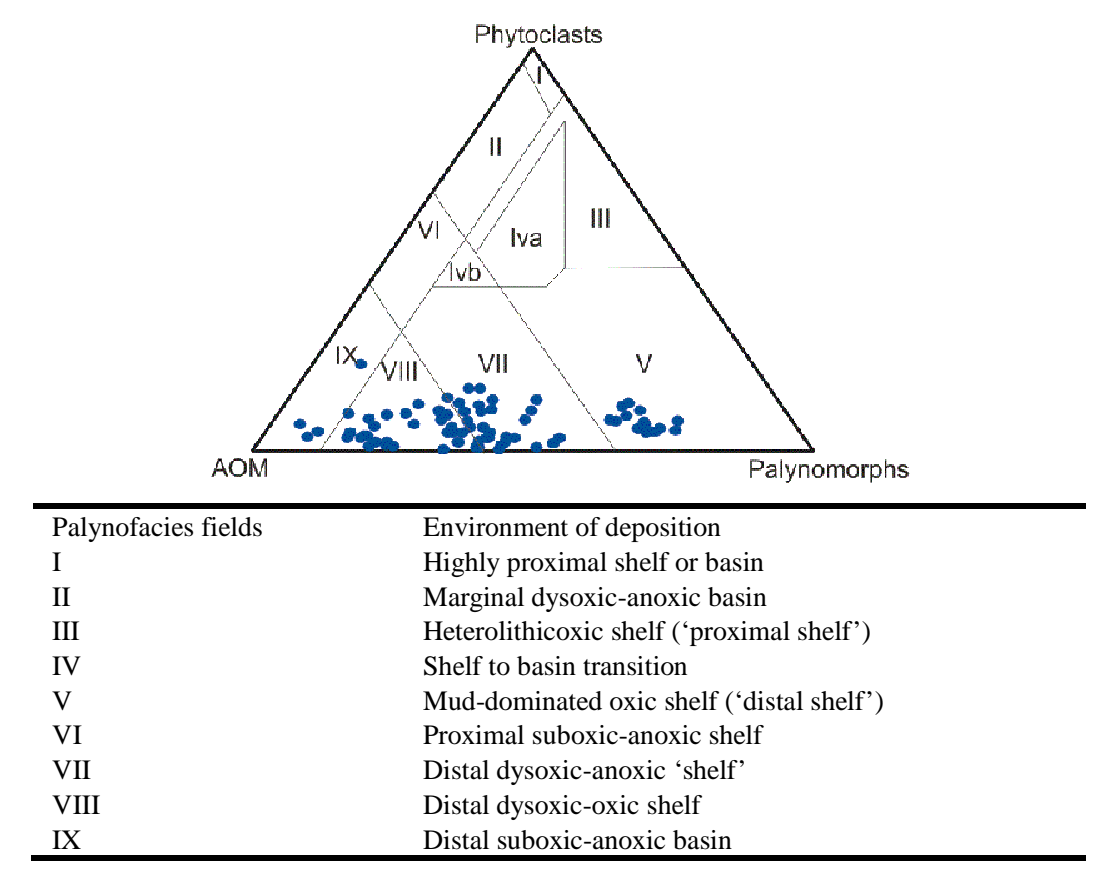

Fig. 4. APP ternary palynofacies diagram used for palaeoenvironmental interpretation [10].

\section{Palynology and Age Assessment}

\subsection{Campanian- Maastrchtian Age}

The terrestrial palynomorphs within the interval (3410$5590 \mathrm{ft}$ ) include Proteacidites dehanni, Echitriporites trianguliformis, Deltoidspora minor, Spinizonocolpites spp. Longapertites spp, Proxapertites spp. These forms have been reported extensively in Campanian-Maastrichtian sediments $\{[24],[25],[26],[27],[28],[29],[30],[31]\}$. Some selected marine palynomorphs found in the interval which support this age include, Senegalinium bicavatum, Cerodinium spp, Phelodium magnificum, Spiniferites spp, Cordosphaeridium spp, Areoligera spp, Palaeocystodium australinum, and Andalusiella spp. These species have been reported extensively in Campanian - Maastrichtian sediments in tropical/subtropical regions $\{[32],[33],[34],[35],[36]\}$.

Typical Turonian - Santonian pollen species are absent in the section. Notably among them are Droseridites senonicus, Cretacaeisporites spp, Zlivisporis blanensis, Hexaporotricolpites spp. Their absence suggests an unconformity between sample depths $5690 \mathrm{ft}$ to $6760 \mathrm{ft}$.

\subsection{Albian- Cenomanian Age}

The interval between $6900 \mathrm{ft}-8550 \mathrm{ft}$ is characterized by the elaterate pollen, Elaterosporites spp, Elaterocolpites spp, Galaecornea spp, and also Ephedripites spp, Classopollis classoides, Reyea polymorphus, Afropollis jardinus, and Cicatricosisporites spp. The elaterate pollen are reported to be restricted to the Albian - Cenomanian Elaterate Province in Africa - South America (ASA) region. These species have been reported from Albian - Cenomanian sediments by [28], [37], [38], [39], [40], [41], [42], [43].

\subsection{Aptian Age}

The age occurs in sample interval, $8660 \mathrm{ft}-9000 \mathrm{ft}$. The interval is characterized by absence of elaterate pollen, and the occurrence of Afropollis jardinus, Deltoidspora sp, Reyea polymorphus, Ephedripites sp, Cicatricosisporites, Perotriletes pannaceus, Cyathidites spp.

A. jardinus has been reported on the world record as a stratigraphic marker for the early Aptian age for regions in equatorial Africa [44]. Elater pollen first appears in the stratigraphic sequence during the early Albian - middle Albian sediments \{[28], [39], [40], [41], [45], [38]\}. The absence of any elater-bearing pollen which is a stratigraphically important element of the Albian Cenomanian, delimits the age of the interval to pre-Albian and suggests an Aptian age. Dinocysts common here are Subtilisphaera sp, Oligospaeridium complex.

\section{Source Rock Evaluation}

Conditions necessary for hydrocarbon formation is the presence of a reducing environment in a subsiding basin where POM in sediments are subjected to enough time and temperature for thermal maturation [46]. In geochemical analysis the first step in hydrocarbon investigation is the measurement of total organic carbon (TOC \%) content of the potential source rock. Other important parameters obtained from Rock-Eval pyrolysis are $S_{1}$, free hydrocarbon; $S_{2}$, pyrolyzed hydrocarbon resulting from the cracking of kerogen; $\mathrm{S}_{3}$, quantity of $\mathrm{CO}_{2}$, and Tmax, the temperature at which the maximum generation of hydrocarbon $\left(\mathrm{S}_{2}\right)$ is observed and measures the thermal maturation [46]. These parameters are used to calculate the following: 
OI, oxygen index $\left.\left[\mathrm{OI}=\left(\mathrm{S}_{3} / \mathrm{TOC}\right) \mathrm{x} 100\right)\right]$ which is related to the amount of $\mathrm{O}_{2}$ in the kerogen [47]; HI, hydrogen index $\left[\mathrm{HI}=\left(\mathrm{S}_{2} / \mathrm{TOC}\right) \times 100\right]$ which indicates the potential of kerogen in a rock to generate petroleum; PI, production index $\left[\mathrm{PI}=\mathrm{S}_{1} /\left(\mathrm{S}_{1}+\mathrm{S}_{2}\right)\right]$ indicating the level of thermal maturation and also the presence of migrated hydrocarbons; Hydrogen richness in the kerogen $=S_{2} / S_{3}$ which indicates the potential of the rock to generate hydrocarbon and Genetic Potential of the source rock $=S_{1}+S_{2}$ which indicates the total amount of petroleum that might be generated from a rock.

\subsection{Organic Carbon Richness and Hydrocarbon \\ Potentiality}

For a rock to be a source of hydrocarbon it must contain sufficient organic matter for generation and expulsion [14]. Carbonate and shale rocks are viewed as source rocks if TOC is in excess of 0.3 and $0.5 \%$ respectively [50], [53].

[47], however, put the minimum organic content of a source rock to be between 1-2\%, while [14], [46], [53] put it at $0.5 \%$. Sediments from ST-7H well have generally TOC $(\%$ of rock) ranging from $0.51-3.45 \%$ with an average of $1.4 \%$ which is above the minimum and are thus of good potential (Table 3).
Table 3. Guidelines for interpreting source rock quantity, quality and maturation, and commonly used Rock-Eval parameters. \{[47], [48], [49], [50], [51], [52]].

\begin{tabular}{llll}
\hline Quantity & TOC & $\begin{array}{l}\mathbf{S}_{\mathbf{1}}(\mathbf{m g} \\
\text { HC/g rock })\end{array}$ & $\begin{array}{l}\mathbf{S}_{2}(\mathbf{m g} \mathbf{H C} / \mathbf{g} \\
\text { rock })\end{array}$ \\
\hline Poor & $<0.5$ & $<0.5$ & $<2.5$ \\
Fair & $0.5-1$ & $0.5-1$ & $2.5-5.0$ \\
Good & $1-2$ & $1-2$ & $5-10$ \\
Very Good & $2-4$ & $2-4$ & $10-20$ \\
Excellent & $>4$ & $>4$ & $>20$ \\
Quality & $\mathrm{HI}(\mathrm{mg}$ HC/g TOC) & $\mathrm{S} 2 / \mathrm{S} 3$ & Kerogen Type \\
None & $<50$ & $<1$ & IV \\
Gas & $50-200$ & $1-5$ & III \\
Gas and Oil & $200-300$ & $5-10$ & II/III \\
Oil & $300-600$ & $10-15$ & II \\
Oil & $>600$ & $>15$ & I \\
Maturation & Ro $(\%)$ & Tmax $\left({ }^{0} \mathrm{C}\right)$ & TAI \\
Immature & $0.2-0.6$ & $<435$ & $1.5-2.6$ \\
Early Mature & $0.6-0.65$ & $435-445$ & $2.6-2.6$ \\
Peak Mature & $0.65-0.9$ & $445-450$ & $2.7-2.9$ \\
Late Mature & $0.9-1.35$ & $450-470$ & $2.9-3.3$ \\
Post Mature & $>1.35$ & $>470$ & $>3.3$ \\
\hline
\end{tabular}

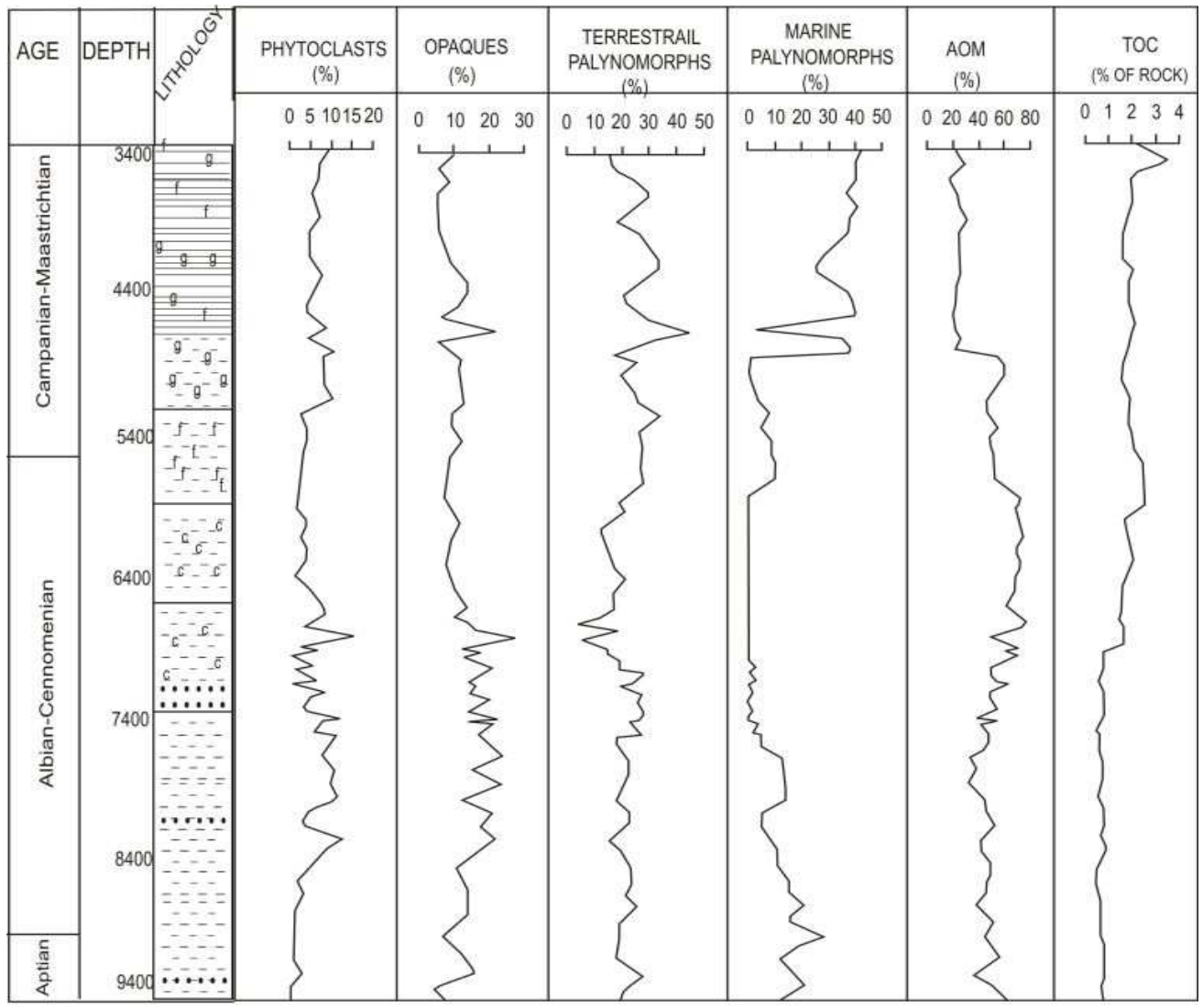

LEGEND

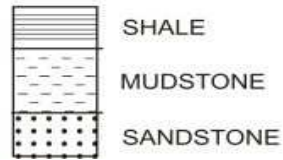

Fig. 5. Distribution of relative abundances of sedimentary organic matter (SOM), palynomorphs and total organic carbon (TOC) against depth for ST-7H well. 
The highest recorded TOC value (1.34-3.45\%) occurred within the interval [(3140-230 ft.) - (6570-650ft)] (Fig. 5), (Appendix 3) with rich AOM indicating a superabundance of organic matter preserved under adequately reducing conditions. This observation is in agreement with [10], [16] [19] who indicated that the percentage values obtained for TOC correlated well with variations in AOM abundance. $54 \%$ of the samples have TOC values of more than $1 \%$ needed to estimate the hydrocarbon potential of ST-7H well. Most of the samples studied have 'fair' to 'very good' petroleum potential on plots of Rock-Eval $S_{2}$ versus TOC (Fig 6a). According to [47], $S_{2}$ measures the existing potential of a rock to generate hydrocarbon, and thus is regarded as a more practical measure of source rock potential than TOC. This is because TOC takes into account inert or dead carbon that is not able to produce hydrocarbons. Therefore data from ST-7H well with $\mathrm{S}_{2}$ values (0.61-7.83; average of 2.97) is a fair potential source rock.

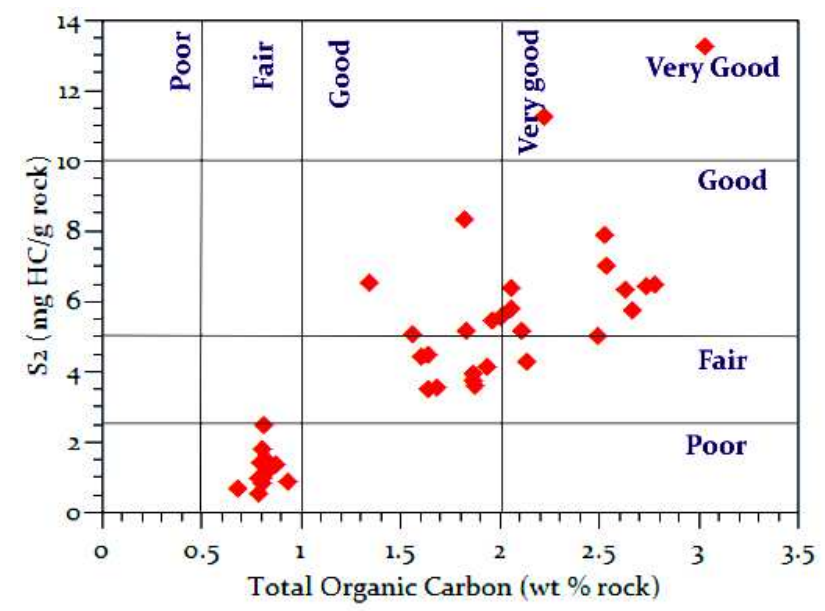

Fig. 6a. Plot of $S_{2}$ versus TOC indicating hydrocarbon potential and source rock efficiency.

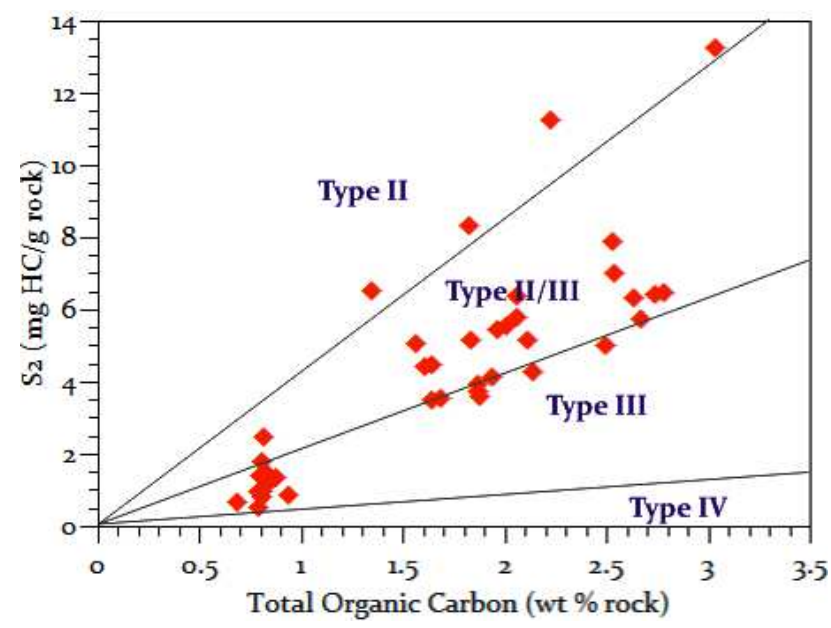

Fig. 6b. Plot of $S_{2}$ versus TOC indicating kerogen type.

The cross plot of $S_{2}$ versus TOC and determining the regression equation according to [54], is the best method for analyzing the true average $\mathrm{HI}$ and measuring the adsorption of hydrocarbon by the rock matrix. HI values from analyzed samples range from 64-504 mg HC/g TOC (ave. $234 \mathrm{mg}$ $\mathrm{HC} / \mathrm{g}$ TOC) indicating a kerogen of mixed type II, II/III and III [46] and yielding oil, oil/gas and gas respectively, but with II/III and III dominant (Fig. 6b).

\subsection{Kerogen Type and Maturity}

Organic geochemical method can be used to identify kerogen types. The type of organic matter is an important factor in evaluating source rock potential. It is very important to determine the kerogen types due to the variation of the chemical structure of organic matters and hydrocarbon products. Four types of kerogen (I, II, III and IV) are identified and values of elemental analysis of $\mathrm{C}, \mathrm{O}$ and $\mathrm{H}$ plotted on the Van-Krevelen diagram [55] can define these kerogen types. Kerogen types can also be identified by plotting HI versus OI on a modified Van-Krevelen diagram [53], [56]. The kerogen designation is based entirely on HI [46], but the kerogen quality and maturity are determined by plotting HI versus Tmax rather than HI versus OI. This eliminates the use of OI as a kerogen type indicator (comparable to $\mathrm{O} / \mathrm{C}$ in the VanKrevelen diagram). Raw data plotting on the modified VanKrevelen diagram (HI versus OI) (Fig. 7) indicate kerogen of mixed type II, II/III and III (oil, oil/gas and gas prone) respectively. The $\mathrm{HI}$ values ranging from $64-504 \mathrm{mg} \mathrm{HC} / \mathrm{g}$ TOC (av. $234 \mathrm{mg} \mathrm{HC/g}$ TOC) also suggests mixed kerogen type II and III. $26 \%$ of the samples have HI of between $50-200$, $51 \%(200-300)$ and $23 \%(300-600)$. This indicates mixed kerogen type II, II/III and III with the type II/III and III dominant (Fig. 7).

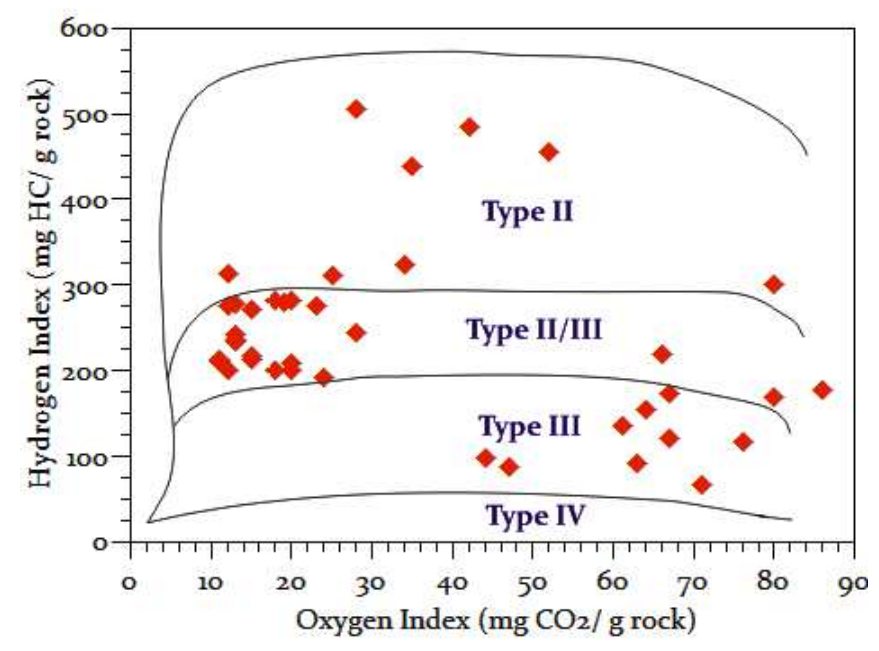

Fig. 7. Plot of Hydrogen Index versus Oxygen Index for ST-7H well showing kerogen types II, II/III and III.

Thermal maturity was evaluated from Rock-Eval Tmax. This is the maximum temperature $\left({ }^{\circ} \mathrm{C}\right)$ reached at the greatest hydrocarbon production $\left(\mathrm{S}_{2}\right)$ when kerogen undergoes thermal cracking between $300-600{ }^{\circ} \mathrm{C}$. It is used together with Thermal Alteration Index (TAI) and Vitrinite Reflectance (Ro) to evaluate thermal maturation [46], [57]. The Tmax values obtained for the samples range from $409-$ $442^{\circ} \mathrm{C}$ (average $431^{\circ} \mathrm{C}$ ), indicating immature to early mature 
kerogen. The thermal maturation of the organic matter was additionally deduced from the Tmax versus HI plot from Rock-Eval pyrolysis (Fig. 8).

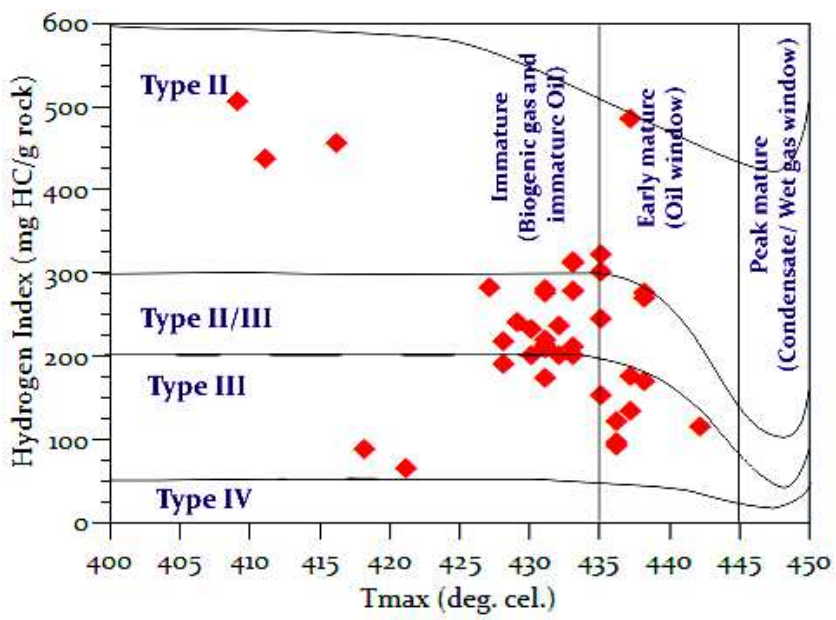

Fig. 8. Plot of Hydrogen Index versus Tmax for ST-7H well indicating thermally immature and early mature kerogen.

The relationship between Tmax and Production Index (PI), is a valuable method for indicating the thermal maturity of organic matter. The following relations between Tmax and PI are observed:

- Immature organic matter has Tmax and PI values less than $430^{\circ} \mathrm{C}$ and 0.10 , respectively;

- Mature organic matter has a range of 0.1-0.4 PI. At the top of oil window, Tmax and PI reach $460^{\circ} \mathrm{C}$ and 0.4 , respectively;

- Mature organic matter within the wet gas-zone has PI values greater than 0.4 ; and

- Post-mature organic matter usually has a high PI value and may reach 1.0 by the end of the dry-gas zone [47], [50], [58].

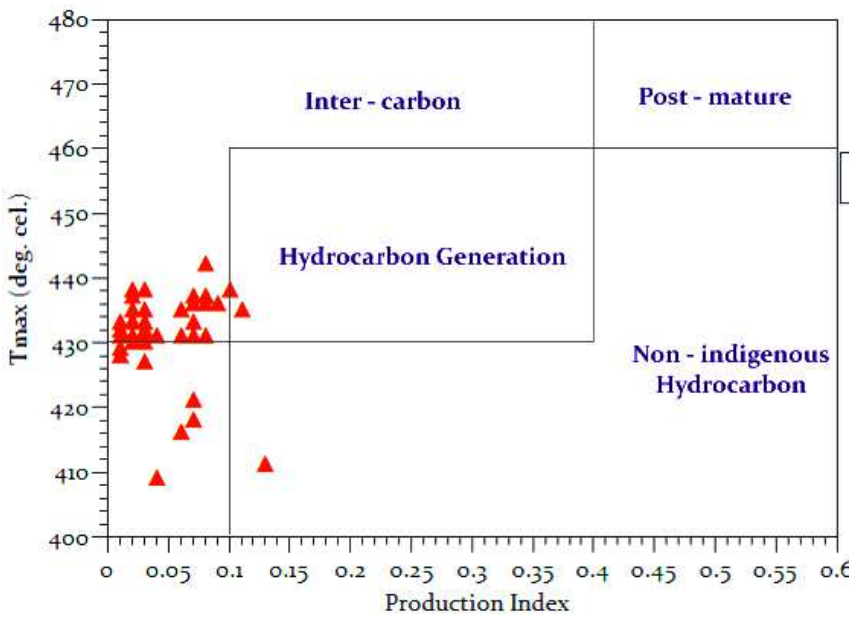

Fig. 9. Plot of Tmax versus Production Index for ST-7H well showing that nearly all samples fall outside the hydrocarbon generating zone.
[53] put the oil generation zone between Tmax temperature of $435^{\circ} \mathrm{C}-460^{\circ} \mathrm{C}$ and between PI values $0.1-$ 0.4. With the Tmax of the samples between $409-442^{\circ} \mathrm{C}$ (average $431^{\circ} \mathrm{C}$ ) and PI values for most of the samples less than 0.1 (Fig. 9), (Appendix 3), it indicates that the in-situ generated hydrocarbons from the samples in the well are low. Most of the samples plot out of the hydrocarbon generation zone and are concentrated in the inert carbon zone (Fig. 9).

\section{Conclusions}

1. Five Palynofacies types have been identified in the ST$7 \mathrm{H}$ well based on sedimentary organic matter associations.

- Palynofacies type I and type IV reflects deposition in a distal dysoxic-anoxic shelf (nearshore) environment.

- Palynofacies type II suggest distal dysoxic to anoxic shelf to deep basin environment with abundant AOM.

- Palynofacies type III is indicative of dysoxic to oxic shelf (fluvio-deltaic) environment of deposition.

- Palynofacies type $\mathrm{V}$ indicates mud-dominated oxic distal shelf environment. The dominance by marine palynomorphs (gonyaulacoid dinocysts) suggests an open marine environment.

2. Palynostratigraphic interpretations assigns sample interval (3410-5590ft) to Campanian - Maastrichtian age, sample interval 6900ft-8550ft to AlbianCenomanian age. An Aptian age is assigned to sediments within intervals (8660ft-9000ft). The Campanian - Maastrichtian age found directly above the Albian - Cenomanian age suggests an unconformity between the interval $5590 \mathrm{ft}$. and $6900 \mathrm{ft}$.

3. From geochemical interpretation, most of the samples from ST-7H well show:

- 'fair' to 'very good' petroleum potential

- kerogen typing from the modified van-Krevelen diagram indicate the presence of mixed kerogen types; Types II, II/III and III kerogens which are oil prone, oil-gas prone and gas prone respectively.

- with regards to thermal maturity, Tmax temperature range of $409-442^{\circ} \mathrm{C}$ indicate immature to early mature hydrocarbons.

- most of samples from the ST-7H well have low Production Index $(<0.10)$ indicating low in-situ hydrocarbon generation.

\section{Acknowledgement}

Authors are grateful to the Ghana National Petroleum Corporation (GNPC) for providing samples and pyrolysis data for the preparation of the manuscript. 


\section{Explanation of Plates}

\section{PLATE I}

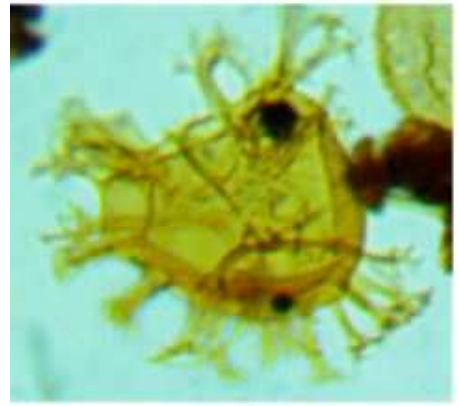

1

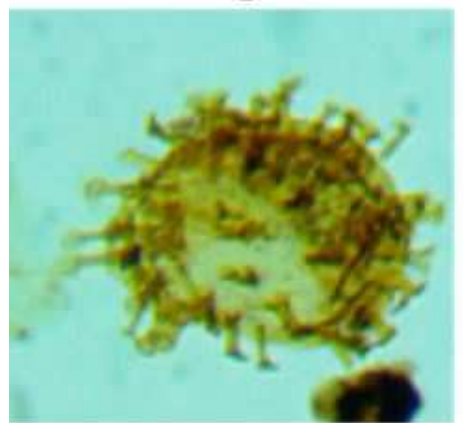

4

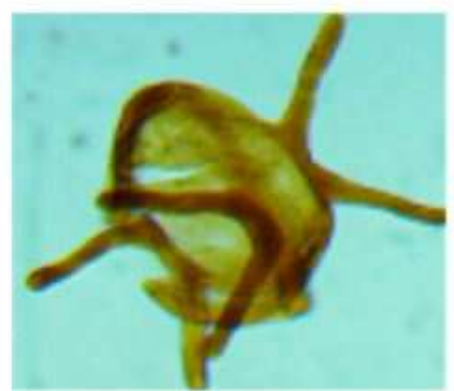

7

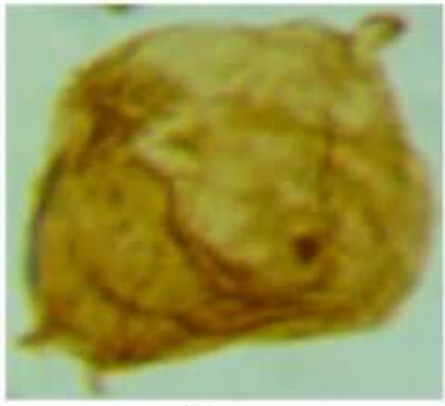

2

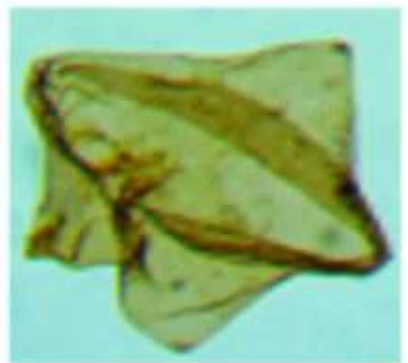

5

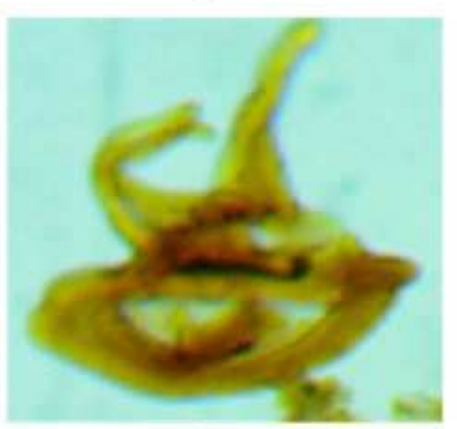

8

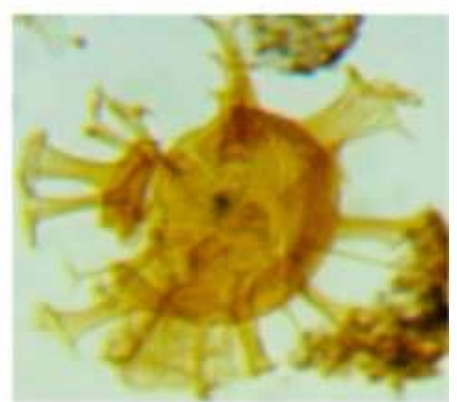

3

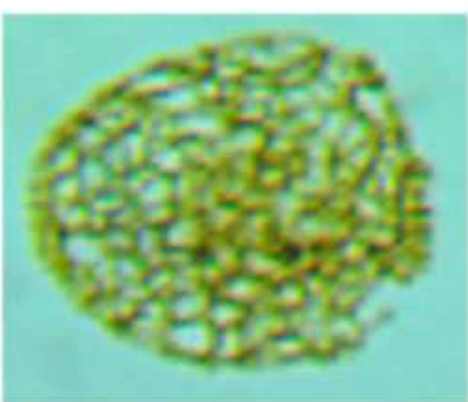

6

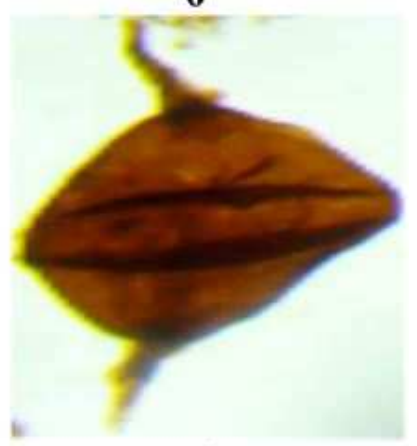

9

Plate I

All figures $\times 550$

Figure

1. Oligophaeridium complex (Whyte) Davey and Williams, 1966

2. Senegalinium laevigatum (Malloy) Bujak and Davies, 1984

3. Cordosphaeridium inodes (Klumpp) Eisenack1963b emend. Morogenroth, 1968

4. Spiniferites $\mathrm{sp}$

5. Phelodium magnificum (Stanley) Stover and Evitt, 1978

6. Afropollis jardinus (Brenner, 1968) Doyle et al., 1982

7. Elaterosporites klaszii (Jardiné et Magloire, 1965) Jardiné, 1967

8. Elaterosporites verrucatus (Jardiné et Magloire, 1965) Jardiné, 1967

9. Palaeocystidinium australinium (Cookson) Lentin and Williams, 1978 


\section{PLATE II}

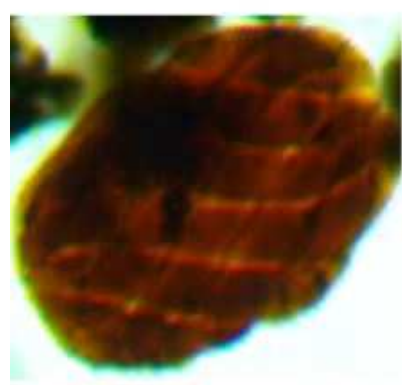

1

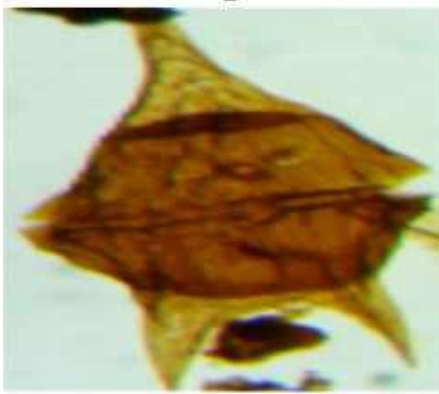

4

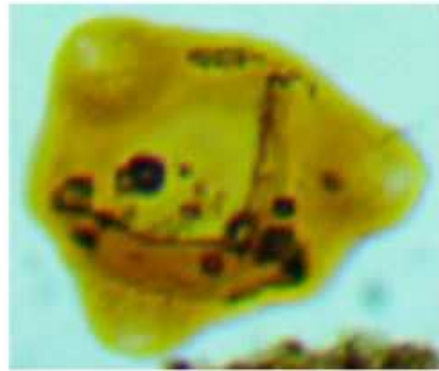

7

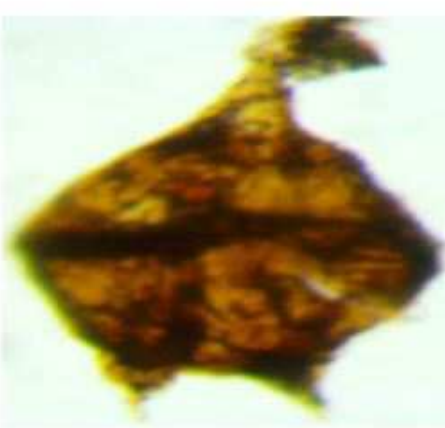

2

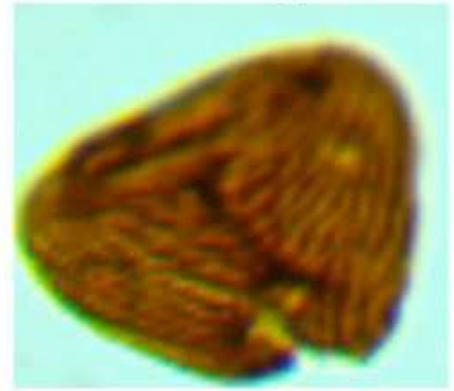

5

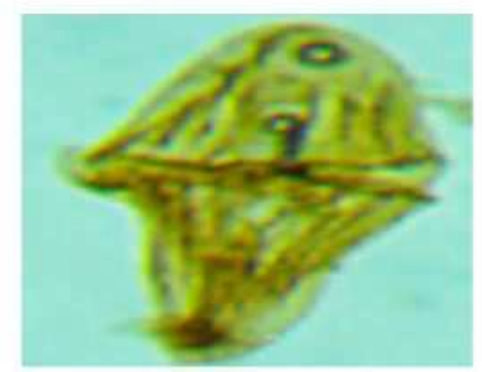

8

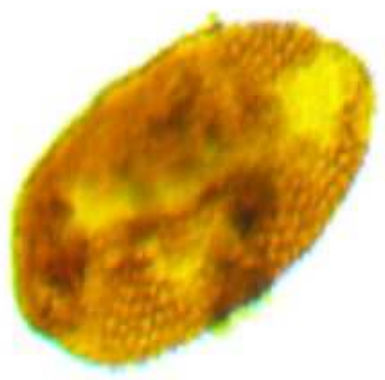

3

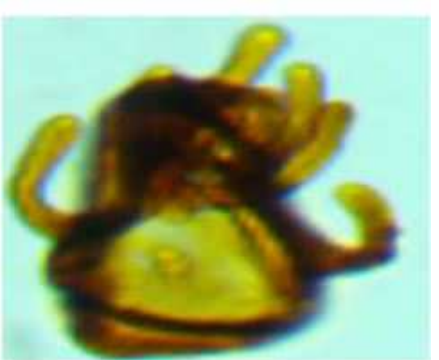

6

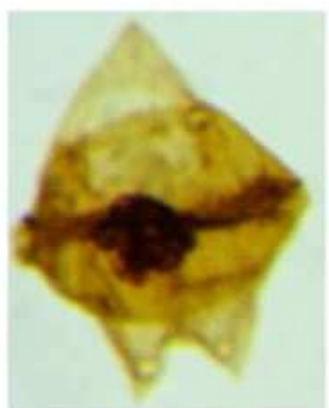

9

Plate II

All figures $\times 550$

Figure

1. Ephedripites $\mathrm{sp}$

2. Cerodinium boloniense (Riegel) Lentin and Williams, 1989

3. Longapertites vaneendenburgi Germeraad, Hopping and Muller, 1968

4. Cerodinium boloniense (Riegel) Lentin and Williams, 1989

5. Cicatricosisporites australiensis (Cookson) Potonié, 1956

6. Elaterosporites verrucatus (Jardiné et Magloire, 1965) Jardiné, 1967

7. Triporites sp.

8. Dinogymnium undulosum Cookson and Eisenack, 1970

9. Cerodinium obliquipes (Deflandre and Cookson) Lentin and Williams, 1989 

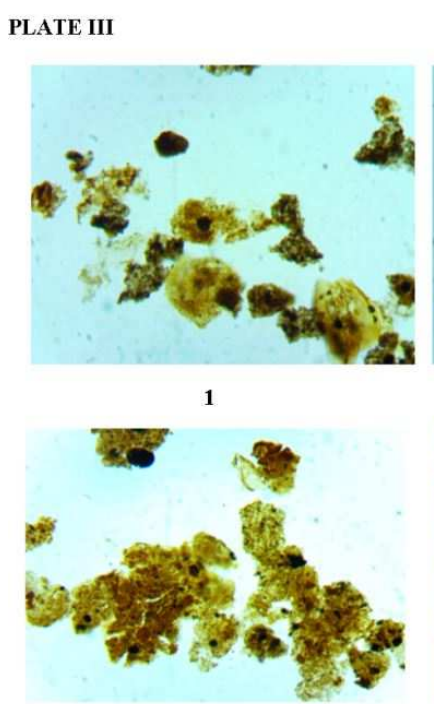

3

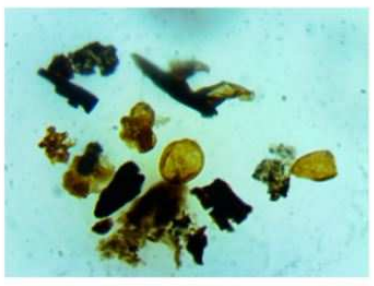

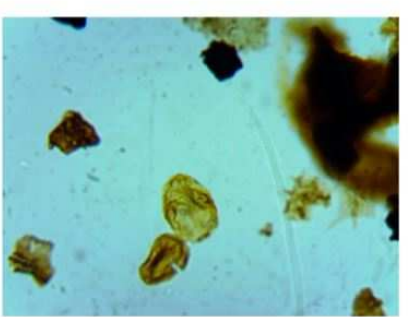

2

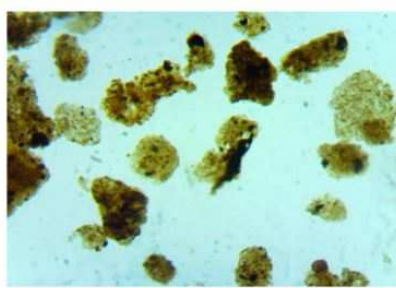

4

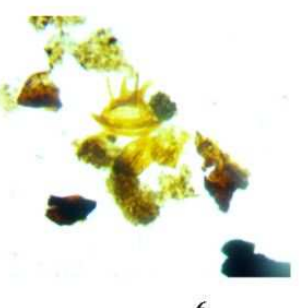

Plate III

All figures $\times 400$

Figure

1, 2. Palynofacies type I and IV (P-I and P-IV). Dominance of AOM with some palynomorphs;

3 4. Palynofacies type II (P-II). Abundant AOM with little phytoclasts;

5, 6. Palynofacies type III (P-III). Equal dominance of AOM and palynomorphs with high opaques.

\section{PLATE IV}

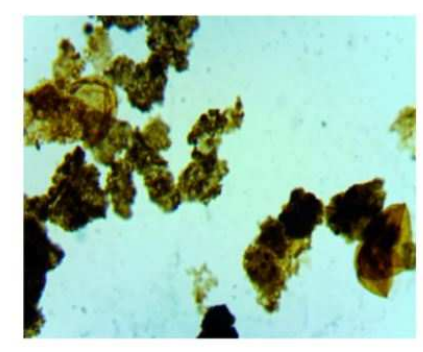

1

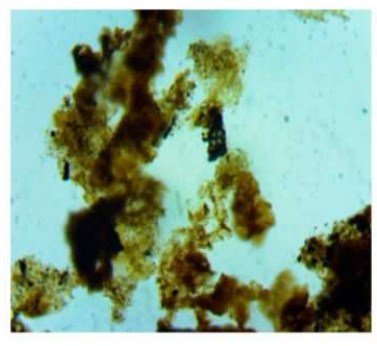

2
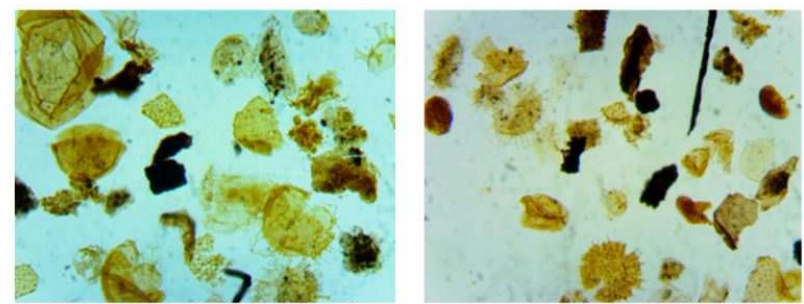

4

Plate IV.

All figures $\times 400$

Figure

1. 2. Palynofacies type IV (P-IV). High amounts of AOM with some palynomorphs and opaques;

3. 4. Palynofacies type V (P-V). High amounts of palynomorphs dominated by marine palynomorphs. 


\section{Appendix 1. Relative Percentage Abundance of SOM and Palynomorphs}

\begin{tabular}{|c|c|c|c|c|}
\hline Depth/Ft & AOM & Opaques & Phytoclasts & Palynomorphs \\
\hline 3410 & 23.1 & 10.0 & 9.20 & 57.7 \\
\hline 3500 & 29.3 & 6.00 & 7.10 & 57.6 \\
\hline 3590 & 18.6 & 8.30 & 6.90 & 66.3 \\
\hline 3680 & 23.1 & 5.10 & 5.40 & 66.4 \\
\hline 3770 & 24.9 & 5.70 & 6.30 & 63.1 \\
\hline 3860 & 30.6 & 5.40 & 7.20 & 56.8 \\
\hline 3950 & 24.6 & 6.00 & 4.60 & 64.8 \\
\hline 4130 & 25.7 & 9.10 & 5.10 & 60.0 \\
\hline 4220 & 25.1 & 12.9 & 7.70 & 54.3 \\
\hline 4310 & 22.6 & 14.0 & 6.30 & 57.1 \\
\hline 4400 & 22.3 & 12.0 & 4.30 & 61.4 \\
\hline 4490 & 20.3 & 7.40 & 4.60 & 67.8 \\
\hline 4580 & 22.3 & 21.4 & 8.70 & 47.6 \\
\hline 4640 & 25.7 & 6.00 & 4.30 & 64.0 \\
\hline 4730 & 24.0 & 10.6 & 10.6 & 54.8 \\
\hline 4770 & 53.1 & 12.0 & 8.00 & 26.8 \\
\hline 4850 & 60.0 & 11.4 & 8.30 & 20.3 \\
\hline 4950 & 54.0 & 12.3 & 8.30 & 25.4 \\
\hline 5050 & 46.9 & 12.9 & 10.0 & 30.3 \\
\hline 5130 & 46.6 & 9.30 & 3.10 & 41.0 \\
\hline 5230 & 54.4 & 9.70 & 4.00 & 31.9 \\
\hline 5310 & 48.6 & 12.1 & 4.00 & 35.3 \\
\hline 5410 & 51.4 & 8.90 & 3.10 & 36.5 \\
\hline 5490 & 51.4 & 8.60 & 2.90 & 37.2 \\
\hline 5590 & 53.5 & 8.00 & 2.30 & 36.2 \\
\hline 5690 & 71.1 & 7.40 & 2.00 & 19.4 \\
\hline 5770 & 68.3 & 9.10 & 1.70 & 20.9 \\
\hline 5850 & 70.9 & 11.4 & 4.00 & 13.7 \\
\hline 5950 & 73.8 & 9.40 & 2.90 & 14.0 \\
\hline 6030 & 69.1 & 8.60 & 4.00 & 18.3 \\
\hline 6130 & 71.5 & 7.70 & 3.40 & 17.4 \\
\hline 6210 & 68.3 & 9.10 & 1.40 & 21.1 \\
\hline 6310 & 67.1 & 10.6 & 5.40 & 16.9 \\
\hline 6410 & 61.7 & 13.4 & 7.70 & 17.1 \\
\hline 6470 & 70.0 & 10.3 & 8.30 & 11.4 \\
\hline 6510 & 75.4 & 14.3 & 5.70 & 4.60 \\
\hline 6550 & 72.0 & 16.0 & 4.00 & 8.00 \\
\hline 6610 & 50.9 & 27.1 & 15.7 & 6.30 \\
\hline 6680 & 68.5 & 13.1 & 2.90 & 15.4 \\
\hline 6700 & 62.0 & 17.4 & 6.60 & 14.0 \\
\hline 6730 & 68.3 & 12.9 & 1.10 & 17.7 \\
\hline 6760 & 63.7 & 14.9 & 1.90 & 19.6 \\
\hline 6800 & 54.0 & 20.0 & 5.40 & 20.6 \\
\hline 6830 & 49.7 & 20.0 & 1.70 & 28.6 \\
\hline 6900 & 53.2 & 14.6 & 6.60 & 25.7 \\
\hline 6920 & 62.0 & 16.3 & 1.10 & 20.6 \\
\hline 6970 & 48.8 & 14.6 & 8.30 & 28.3 \\
\hline 7020 & 49.1 & 20.0 & 4.60 & 26.3 \\
\hline 7100 & 53.0 & 14.4 & 3.90 & 28.7 \\
\hline 7150 & 40.0 & 22.0 & 12.0 & 26.0 \\
\hline 7160 & 52.6 & 14.6 & 8.60 & 24.3 \\
\hline
\end{tabular}




\begin{tabular}{|c|c|c|c|c|}
\hline Depth/Ft & AOM & Opaques & Phytoclasts & Palynomorphs \\
\hline 7180 & 42.8 & 20.9 & 7.70 & 28.5 \\
\hline 7240 & 47.1 & 18.6 & 6.00 & 28.3 \\
\hline 7260 & 48.3 & 17.3 & 10.9 & 23.5 \\
\hline 7340 & 45.1 & 20.9 & 9.40 & 24.6 \\
\hline 7400 & 34.5 & 23.4 & 7.70 & 34.3 \\
\hline 7480 & 38.1 & 15.4 & 10.5 & 36.0 \\
\hline 7580 & 32.9 & 23.1 & 9.70 & 34.3 \\
\hline 7680 & 44.3 & 12.6 & 11.1 & 32.1 \\
\hline 7760 & 46.2 & 20.5 & 4.80 & 28.5 \\
\hline 7860 & 51.7 & 17.7 & 3.70 & 26.9 \\
\hline 7940 & 42.0 & 21.4 & 12.3 & 24.2 \\
\hline 8020 & 42.8 & 17.4 & 8.60 & 31.1 \\
\hline 8120 & 49.5 & 11.1 & 5.10 & 34.2 \\
\hline 8220 & 46.8 & 12.6 & 2.00 & 38.6 \\
\hline 8300 & 45.4 & 14.0 & 3.10 & 37.4 \\
\hline 8380 & 38.9 & 14.0 & 1.70 & 45.4 \\
\hline 8480 & 51.4 & 12.9 & 0.90 & 34.8 \\
\hline 8580 & 45.1 & 7.10 & 0.90 & 46.8 \\
\hline 8660 & 53.7 & 9.70 & 0.90 & 35.8 \\
\hline 8740 & 54.3 & 13.7 & 1.10 & 30.9 \\
\hline 8840 & 36.9 & 14.9 & 2.90 & 45.4 \\
\hline 8920 & 52.9 & 5.10 & 0.30 & 41.7 \\
\hline 9000 & 60.9 & 7.10 & 0.30 & 31.7 \\
\hline
\end{tabular}

\section{Appendix 2. Relative Percentage Abundance of Palynomorphs}

\begin{tabular}{|c|c|c|c|c|c|}
\hline & Terrestrial & Marine & & & Total palynomorphs \\
\hline Depth/ft & Spores/ Pollens & Gonyaulacoids & Peridinoids & Total marine & \\
\hline 3410 & 16.0 & 40.3 & 1.40 & 41.7 & 57.7 \\
\hline 3500 & 17.6 & 37.3 & 2.70 & 40.0 & 57.6 \\
\hline 3590 & 26.3 & 37.3 & 2.70 & 40.0 & 66.3 \\
\hline 3680 & 29.4 & 33.1 & 3.90 & 37.0 & 66.4 \\
\hline 3770 & 22.7 & 33.7 & 6.70 & 40.4 & 63.1 \\
\hline 3860 & 19.3 & 29.4 & 8.10 & 37.5 & 56.8 \\
\hline 3950 & 28.1 & 25.0 & 11.7 & 36.7 & 64.8 \\
\hline 4130 & 33.7 & 13.4 & 12.9 & 26.3 & 60.0 \\
\hline 4220 & 28.0 & 14.0 & 12.3 & 26.3 & 54.3 \\
\hline 4310 & 21.1 & 12.9 & 23.1 & 36.0 & 57.1 \\
\hline 4400 & 22.6 & 13.1 & 25.4 & 38.5 & 61.1 \\
\hline 4490 & 28.9 & 8.00 & 30.9 & 38.9 & 67.8 \\
\hline 4580 & 44.1 & 1.60 & 1.90 & 3.50 & 47.6 \\
\hline 4640 & 29.1 & 10.3 & 24.6 & 34.9 & 64.0 \\
\hline 4730 & 18.0 & 13.7 & 23.1 & 36.8 & 54.8 \\
\hline 4770 & 25.1 & 0.00 & 1.70 & 1.70 & 26.8 \\
\hline 4850 & 20.0 & 0.00 & 0.30 & 0.30 & 20.3 \\
\hline 4950 & 24.0 & 0.00 & 1.40 & 1.40 & 25.4 \\
\hline 5050 & 26.6 & 0.06 & 3.10 & 3.70 & 30.3 \\
\hline 5130 & 33.3 & 3.10 & 4.60 & 7.70 & 41.0 \\
\hline 5230 & 26.9 & 3.00 & 2.00 & 5.00 & 31.9 \\
\hline 5310 & 27.1 & 6.90 & 1.30 & 8.20 & 35.3 \\
\hline 5410 & 27.7 & 7.70 & 1.10 & 8.80 & 36.5 \\
\hline 5490 & 26.9 & 9.40 & 0.90 & 10.3 & 37.2 \\
\hline
\end{tabular}




\begin{tabular}{|c|c|c|c|c|c|}
\hline & Terrestrial & Marine & & & Total palynomorphs \\
\hline Depth/ft & Spores/ Pollens & Gonyaulacoids & Peridinoids & Total marine & \\
\hline 5590 & 27.4 & 7.70 & 1.10 & 8.80 & 36.2 \\
\hline 5690 & 19.4 & 0.00 & 0.00 & 0.00 & 19.4 \\
\hline 5770 & 20.9 & 0.00 & 0.00 & 0.00 & 20.9 \\
\hline 5850 & 13.3 & 0.00 & 0.00 & 0.00 & 13.7 \\
\hline 5950 & 14.0 & 0.00 & 0.00 & 0.00 & 14.0 \\
\hline 6030 & 18.3 & 0.00 & 0.00 & 0.00 & 18.3 \\
\hline 6130 & 17.4 & 0.00 & 0.00 & 0.00 & 17.4 \\
\hline 6210 & 21.1 & 0.00 & 0.00 & 0.00 & 21.1 \\
\hline 6310 & 16.9 & 0.00 & 0.00 & 0.00 & 16.9 \\
\hline 6410 & 17.1 & 0.00 & 0.00 & 0.00 & 17.1 \\
\hline 6470 & 11.4 & 0.00 & 0.00 & 0.00 & 11.4 \\
\hline 6510 & 4.60 & 0.00 & 0.00 & 0.00 & 4.60 \\
\hline 6550 & 8.00 & 0.00 & 0.00 & 0.00 & 8.00 \\
\hline 6610 & 6.30 & 0.00 & 0.00 & 0.00 & 6.30 \\
\hline 6680 & 15.4 & 0.00 & 0.00 & 0.00 & 15.4 \\
\hline 6700 & 14.0 & 0.00 & 0.00 & 0.00 & 14.0 \\
\hline 6730 & 17.7 & 0.00 & 0.00 & 0.00 & 17.7 \\
\hline 6760 & 19.6 & 0.00 & 0.00 & 0.00 & 19.6 \\
\hline 6800 & 18.6 & 1.10 & 0.90 & 2.00 & 20.6 \\
\hline 6830 & 27.6 & 0.80 & 0.20 & 1.00 & 28.6 \\
\hline 6900 & 23.7 & 1.00 & 1.00 & 2.00 & 25.7 \\
\hline 6920 & 20.0 & 0.30 & 0.30 & 0.60 & 20.6 \\
\hline 6970 & 27.0 & 1.00 & 0.30 & 1.30 & 28.3 \\
\hline 7020 & 26.0 & 0.30 & 0.00 & 0.30 & 26.3 \\
\hline 7100 & 27.7 & 0.70 & 0.30 & 1.00 & 28.7 \\
\hline 7150 & 25.7 & 0.00 & 0.00 & 0.00 & 25.7 \\
\hline 7160 & 23.4 & 0.90 & 0.00 & 0.90 & 24.3 \\
\hline 7180 & 25.1 & 3.10 & 0.30 & 3.40 & 28.5 \\
\hline 7240 & 26.4 & 1.60 & 0.30 & 1.90 & 28.3 \\
\hline 7260 & 18.7 & 3.90 & 0.90 & 4.80 & 23.5 \\
\hline 7340 & 19.1 & 4.00 & 1.50 & 5.50 & 24.6 \\
\hline 7400 & 22.3 & 6.60 & 5.40 & 12.0 & 34.3 \\
\hline 7480 & 22.9 & 7.10 & 6.00 & 13.1 & 36.0 \\
\hline 7580 & 20.6 & 6.30 & 7.40 & 13.7 & 34.3 \\
\hline 7680 & 18.3 & 6.90 & 6.90 & 13.8 & 32.1 \\
\hline 7760 & 22.9 & 4.80 & 0.80 & 5.60 & 28.5 \\
\hline 7860 & 21.7 & 4.60 & 0.60 & 5.20 & 26.9 \\
\hline 7940 & 16.0 & 7.10 & 1.10 & 8.20 & 24.2 \\
\hline 8020 & 20.3 & 9.70 & 1.10 & 10.8 & 31.1 \\
\hline 8120 & 23.2 & 8.60 & 2.40 & 11.0 & 34.2 \\
\hline 8220 & 23.7 & 12.9 & 2.00 & 14.9 & 38.6 \\
\hline 8300 & 21.7 & 14.0 & 1.70 & 15.7 & 37.4 \\
\hline 8380 & 25.1 & 18.6 & 1.70 & 20.3 & 45.4 \\
\hline 8480 & 19.4 & 15.1 & 0.30 & 15.4 & 34.8 \\
\hline 8580 & 19.1 & 26.3 & 1.40 & 27.7 & 46.8 \\
\hline 8660 & 18.3 & 16.6 & 0.90 & 17.5 & 35.8 \\
\hline 8740 & 18.6 & 11.7 & 0.60 & 12.3 & 30.9 \\
\hline 8840 & 27.4 & 16.9 & 1.10 & 18.0 & 45.4 \\
\hline 8920 & 21.4 & 19.4 & 0.90 & 20.3 & 41.7 \\
\hline 9000 & 19.3 & 11.7 & 0.70 & 12.4 & 31.7 \\
\hline
\end{tabular}


Appendix 3. Rock-Eval pyrolysis/TOC Data for the ST-7H Well

\begin{tabular}{|c|c|c|c|c|c|c|c|c|c|}
\hline \multirow{2}{*}{$\begin{array}{l}\text { SAMPLE DEPTH } \\
\text { (Feet) }\end{array}$} & \multicolumn{4}{|c|}{ TOC \% OF } & \multicolumn{5}{|c|}{ PYROLYSIS } \\
\hline & ROCK & S1 & S2 & S3 & HI & OI & PI & Tmax & $\mathbf{S} 2 / \mathbf{S 3}$ \\
\hline \multirow[t]{3}{*}{$3140-230$} & 0.88 & & & & & & & & \\
\hline & 1.16 & & & & & & & & \\
\hline & 2 & 70 & 5480 & 460 & 274 & 23 & 0.01 & 431 & 11.91 \\
\hline \multirow[t]{2}{*}{$3230-320$} & 1.87 & 50 & 3540 & 440 & 189 & 24 & 0.01 & 431 & 8.05 \\
\hline & 2.4 & & & & & & & & \\
\hline $3320-410$ & 2.66 & 70 & 5720 & 390 & 215 & 15 & 0.01 & 428 & 14.67 \\
\hline \multirow[t]{3}{*}{$3410-500$} & 2.13 & & & & & & & & \\
\hline & 2.63 & 50 & 6280 & 350 & 239 & 13 & 0.01 & 426 & 1794 \\
\hline & 1.64 & & & & & & & & \\
\hline \multirow[t]{2}{*}{$3500-590$} & 1.95 & & & & & & & & \\
\hline & 2.78 & 110 & 6410 & 360 & 231 & 13 & 0.02 & 430 & 17.1 \\
\hline \multirow[t]{2}{*}{$3590-680$} & 3.45 & & & & & & & & \\
\hline & 2.73 & 60 & 6390 & 360 & 234 & 13 & 0.01 & 432 & 17.75 \\
\hline \multirow[t]{3}{*}{$3680-770$} & 1.86 & & & & & & & & \\
\hline & 2.49 & 70 & 4960 & 310 & 199 & 12 & 0.01 & 433 & 16 \\
\hline & 0.92 & & & & & & & & \\
\hline $3770-950$ & 1.68 & 90 & 3480 & 330 & 207 & 20 & 0.03 & 431 & 10.55 \\
\hline $3860-950$ & 1.58 & & & & & & & & \\
\hline $3950-4040$ & 2.05 & 150 & 5750 & 360 & 280 & 18 & 0.03 & 427 & 15.97 \\
\hline 4040-130 & 1.86 & 100 & 3710 & 370 & 199 & 20 & 0.03 & 430 & 14.54 \\
\hline $4130-220$ & 1.82 & & & & & & & & \\
\hline $4220-310$ & 1.93 & 150 & 4070 & 280 & 211 & 15 & 0.04 & 431 & 14.54 \\
\hline $4310-400$ & 2.13 & 140 & 4230 & 380 & 199 & 18 & 0.03 & 432 & 11.13 \\
\hline $4400-490$ & 1.97 & & & & & & & & \\
\hline $440-580$ & 1.86 & 250 & 3870 & 210 & 208 & 11 & 0.06 & 431 & 18.43 \\
\hline $4580-670$ & 1.73 & & & & & & & & \\
\hline $4670-730$ & 1.64 & 240 & 3440 & 180 & 210 & 11 & 0.07 & 433 & 19.11 \\
\hline $4770-850$ & 1.6 & & & & & & & & \\
\hline $4850-930$ & 1.87 & & & & & & & & \\
\hline $4930-5010$ & 1.96 & 110 & 5420 & 380 & 277 & 19 & 0.02 & 433 & 14.26 \\
\hline 5010-090 & 1.86 & & & & & & & & \\
\hline $5090-170$ & 2 & & & & & & & & \\
\hline $5170-250$ & 2.11 & 130 & 5130 & 600 & 243 & 28 & 0.02 & 435 & 8.55 \\
\hline $5250-330$ & 2.45 & & & & & & & & \\
\hline $5330-410$ & 2.53 & 120 & 6980 & 320 & 276 & 13 & 0.02 & 433 & 21.81 \\
\hline $5410-490$ & 2.49 & & & & & & & & \\
\hline $5490-570$ & 2.52 & 140 & 7830 & 300 & 311 & 12 & 0.02 & 433 & 26.1 \\
\hline $5570-650$ & 1.71 & & & & & & & & \\
\hline $5650-730$ & 1.83 & 100 & 5110 & 360 & 279 & 20 & 0.02 & 431 & 14.19 \\
\hline $5730-810$ & 1.87 & & & & & & & & \\
\hline $5810-890$ & 2.05 & 170 & 6330 & 510 & 309 & 25 & 0.03 & 433 & 12.41 \\
\hline 5890-970 & 1.86 & & & & & & & & \\
\hline $5970-6050$ & 1.59 & & & & & & & & \\
\hline $6050-130$ & 1.56 & 170 & 5000 & 530 & 321 & 34 & 0.03 & 435 & 9.43 \\
\hline
\end{tabular}




\begin{tabular}{|c|c|c|c|c|c|c|c|c|c|}
\hline \multirow{2}{*}{$\begin{array}{l}\text { SAMPLE DEPTH } \\
\text { (Feet) }\end{array}$} & \multicolumn{4}{|c|}{ TOC \% OF } & \multicolumn{5}{|c|}{ PYROLYSIS } \\
\hline & ROCK & S1 & S2 & S3 & HI & OI & PI & Tmax & $\mathbf{S} 2 / \mathrm{S3}$ \\
\hline $6130-210$ & 1.53 & & & & & & & & \\
\hline $6210-290$ & 1.48 & & & & & & & & \\
\hline $6270-370$ & 1.6 & 120 & 4380 & 190 & 274 & 12 & 0.03 & 438 & 23.05 \\
\hline $6370-450$ & 1.64 & 80 & 4410 & 240 & 269 & 15 & 0.02 & 438 & 18.38 \\
\hline $6490-570$ & 1.58 & & & & & & & & \\
\hline $6570-650$ & 1.34 & 100 & 6470 & 560 & 504 & 42 & 0.02 & 409 & 11.55 \\
\hline $6650-730$ & 0.74 & & & & & & & & \\
\hline $6730-810$ & 0.81 & 150 & 2420 & 650 & 299 & 800 & 0.06 & 435 & 3.72 \\
\hline $6810-890$ & 0.79 & & & & & & & & \\
\hline 6890-970 & 0.77 & & & & & & & & \\
\hline $6970-7050$ & 0.65 & & & & & & & & \\
\hline $7050-130$ & 0.82 & 100 & 1090 & 500 & 133 & 61 & 0.08 & 437 & 2.18 \\
\hline \multicolumn{10}{|l|}{$7130-210$} \\
\hline $6700-780$ & 0.61 & & & & & & & & \\
\hline $6780-860$ & 0.75 & & & & & & & & \\
\hline $6860-940$ & 0.8 & 80 & 910 & 610 & 114 & 76 & 0.08 & 442 & 1.49 \\
\hline $6940-7020$ & 0.81 & & & & & & & & \\
\hline $7020-100$ & 0.83 & 150 & 1390 & 660 & 167 & 80 & 0 & 438 & 2.11 \\
\hline $711-180$ & 0.7 & & & & & & & & \\
\hline $7180-260$ & 0.68 & & & & & & & & \\
\hline $7260-340$ & 0.51 & & & & & & & & \\
\hline $7340-420$ & 0.66 & & & & & & & & \\
\hline $7420-500$ & 0.58 & & & & & & & & \\
\hline $7500-580$ & 0.65 & & & & & & & & \\
\hline $7580-660$ & 0.8 & 160 & 1740 & 530 & 218 & 66 & 0.08 & 431 & 3.28 \\
\hline $7660-740$ & 0.73 & & & & & & & & \\
\hline $7130-20$ & 0.58 & & & & & & & & \\
\hline $7210-290$ & 0.79 & 100 & 1380 & 680 & 175 & 86 & 0.07 & 437 & 2.03 \\
\hline $7290-370$ & 0.79 & & & & & & & & \\
\hline $7740-820$ & 0.7 & & & & & & & & \\
\hline $7820-900$ & 0.87 & 160 & 1320 & 560 & 152 & 64 & 0.11 & 435 & 2.36 \\
\hline $7900-980$ & 0.56 & & & & & & & & \\
\hline $7980-8060$ & 0.43 & & & & & & & & \\
\hline $8060-140$ & 0.56 & & & & & & & & \\
\hline $8140-220$ & 0.68 & 50 & 610 & 430 & 64 & 63 & 0.08 & 436 & 1.42 \\
\hline $8220-300$ & 0.69 & & & & & & & & \\
\hline $8300-380$ & 0.66 & & & & & & & & \\
\hline $8380-460$ & 0.8 & 60 & 760 & 350 & 95 & 44 & 0.07 & 436 & 2.17 \\
\hline $8460-540$ & 0.78 & & & & & & & & \\
\hline $8540-620$ & 0.82 & 100 & 1410 & 550 & 172 & 67 & 0.07 & 431 & 2.56 \\
\hline $8620-700$ & 0.7 & & & & & & & & \\
\hline $8700-780$ & 0.72 & & & & & & & & \\
\hline $8780-860$ & 0.78 & 90 & 930 & 520 & 119 & 67 & 0.09 & 436 & 1.79 \\
\hline $8860-940$ & 0.76 & & & & & & & & \\
\hline $8940-9000$ & 0.65 & & & & & & & & \\
\hline
\end{tabular}




\section{References}

[1] Kesse, G.O. Mineral and Rock Resources of Ghana. AA. Balkema Publishers. Rotterdam, the Netherlands. 610 pp., 1985.

[2] Davies, G. Geological and tectonic framework of the Republic of Ghana and petroleum geology of the Tano Basin, Southwestern Ghana. Unpublished consultancy report prepared for Petro-Canada International Corporation on behalf of GNPC. 1989.

[3] GNPC. Offshore Activity Map. 1994.

[4] Combaz, A. Les palynofaciès. Revue de Micropalaeontologie, 7, $205-218,1964$

[5] Batten, D.J. Palynofacies, organic maturation and source potential for petroleum. In Brooks, J. (Ed.), Organic maturation studies and fossil fuel exploration. Academic Press, London, 201-223, 1981.

[6] Batten, D.J. Palynofacies, palaeoenvironment, and petroleum. Journal of Micropalaeontology, 1,107 - 114, 1982.

[7] Van der Zwan, C.J. Palynostratigraphy and palynofacies reconstruction of the upper Jurassic to lowermost Cretaceous of the Draugen Field, offshore mid Norway. Review of Palaeobotany and Palynology, 62, 157 - 186, 1990.

[8] Fischer, M..J. Kerogen distribution and depositional environments in the Middle Jurassic of Yorkshire, UK. In D. C. Bharadwaj, H. P. Singh and R. S. Tiwari (Ed.), Proceeding of the IV International Palynologist Conference, Lucknow, India, (1976-77), 2, 574-580, 1980.

[9] Boulter, M.C., Riddick, A. Classification and analysis of palynodebris from the Palaeocene sediments of the Forties Field. Sedimentology, 33, $871-886,1986$.

[10] Tyson, R.V. Sedimentary Organic Matter: Organic Facies and Palynofacies. Chapman and Hall, London, 615 pp., 1995.

[11] Batten, D.J. dentification of amorphous sedimentary organic matter by transmitted light microscopy. In Brooks, J. (Ed.), Petroleum geochemistry and exploration of Europe, Geological Society Special Publication 12, Blackwell Science, Oxford, $275-287,1983$.

[12] Tyson, R.V. Palynofacies analysis. In: Jenkins D.G., (Ed), Applied Micropalaeontology, Kluwer Academic Publishers, Dordrecht, 153 - 191, 1993.

[13] Kholeif, S.H., Ibrahim, M.I. Palynofacies analysis of inner continental shelf and middle slope sediments offshore Egypt, Southeastern Mediterranean. Geobios, 43, 333 - 347, 2010.

[14] Batten, D.J. Palynofacies and paleoenvironmental interpretation. In Jansonius, J., McGregor, D.C., (Eds.), Palynology: Principles and applications; American Association of Stratigraphic Palynologists, Foundation 3, 1011-1064, 1996

[15] Al-Ameri, T.K., Al-Najar, T.K., Batten, D.J. Palynostratigraphy and Palynofacies indications of depositional environments and source potential for hydrocarbons: The Mid Cretaceous Nahr Umr and lower Mauddud formations, Iraq. Cretaceous Research, 22, 735-742, 2001.
[16] Carvalho, M.A., Filho, J.G.M., Menezes, T.R. Paleoenvironmental reconstruction based on palynofacies analysis of the Aptian - Albian succession of the Sergipe Basin, Northeastern Brazil. Marine Micropaleontology, 59, 56 $-81,2006$.

[17] Martinez, M.A., Pramparo, M.B., Quattrocchio, M.E., Zavala, C.A. Depositional environment and hydrocarbon potential of the Middle Jurassic Los Molles Formation, Neuquen Basin, Argentina: palynofacies and organic geochemical data .Revista Geologica de Chile, 35, 279 - 305, 2008.

[18] Quattrocchio, M.E., Martinez, M.A., Pavisich, A.C., Volkheimer, W. Early Cretaceous palynostratigraphy, palynofacies and palaeoenvironments of well sections in northeastern Tierra del Fuego, Argentina. Cretaceous Research, $27,584-602,2006$.

[19] Tyson, R.V. Late Jurassic palynofacies trends, Piper and Kimmeridge Clay Formation, UK onshore and offshore. In: Batten D. J. and Keen M. C., (Eds.), Northwest European micropalaeontology and palynology, British Micropalaeontological Society Series, 135-172, 1989.

[20] Alaug, A.S. Hydrocarbon potential of the Upper Cretaceous succession at well 16/U-1, offshore Qamar Basin, Eastern Yemen. Journal of Petroleum Geology, 34 (1), 87 - 108, 2011.

[21] Al-Ameri, T.K., Al-Musawi, F.S., Batten, D.J. Palynofacies indications of depositional environments and source potential for hydrocarbon: uppermost Jurassic-basal Cretaceous Sulaiy Formation, southern Iraq. Cretaceous Research, 20, 359 - 363, 1999.

[22] Carvalho, M.A., Ramos, R.R. C., Crud, M.B., Witovisk, L., Kellner, A.W.A., de P. Silva, H., Grillo, O.N., Riff, D., Romano, P.S.R. Palynofacies as indicators of palaeoenvironmental changes in a Cretaceous succession from the Larsen Basin, James Ross Island, Antarctica. Sedimentary Geology, 295, 53 - 66, 2013.

[23] Pocknall, D.T., Turnbull, I.M. Paleoenvironmental and stratigraphic significance of palynomorphs from the Upper Eocene (Kaiatan) Beaumont Coal Measures and Orauea Mudstone, Waiau Basin, Western Southland, New Zealand. New Zealand Journal of Geology and Geophysics, 32,361-368, 1989.

[24] Salami, M.B. Petrography and palynology of the Upper Maastrichtian Abeokuta formation of southwestern Nigeria. Nigerian Journal of Science, 22, (1 \& 2), 127 - 140, 1988.

[25] Salami, M.B. Palynomorph taxa from the "Lower Coal Measures" deposits (? Campanian - Maastrichtian) of Anambra Trough, Southwestern Nigeria. Journal of African Earth Science, 11, 135 - 150, 1990.

[26] Schrank, E. Paleozoic and Mesozoic palynomorphs from northeast Africa (Egypt and Sudan) with special reference to late Cretaceous pollen and dinoflagellates. Berliner Geowissenschaftliche Abhandlungen A, 75, (1) 249-310, 1987.

[27] Schrank, E. Palynology of the Yesomma formation in the northern Somalia: a study of pollen, spores and associated phytoplankton from the Late Cretaceous Palmae province. Palaeontographica Abt. B, 321, (1 - 6), 63 - 112, 1994.

[28] Herngreen G.F.W. Palynology of Middle and Upper Cretaceous strata in Brazil. Mededelingen Rijks Geologische Dienst, NieuweSerie, 26 (3), 39-91, 1975. 
[29] Herngreen, G.F.W. Microfloral relationships between Africa and South America in Middle and Upper Cretaceous time. Proceedings of 4th International Palynologist Conference, Lucknow, (1976 - 77), 1981.

[30] Germeraad, J.H., Hopping, C.A., Muller, J. Palynology of Tertiary sediments from tropical areas. Review of Paleobotany and Palynology, 6, 189 - 348, 1968.

[31] Schrank, E., Ibrahim, and M.I.A. Cretaceous (Aptian Maastrichtian) palynology of foraminifera dated wells (KRM 1, AG - 18) in northwestern Egypt. Berliner Geowissenschaftliche Abhandlungen A, 177, 1 - 44, 1995.

[32] Stover, L.E., Brinkhuis, H.,Damassa, S.P., de Verteuil, L.,Helby, R.J.,Monteil, E., Partridge, A.D., Powell, A.J., Riding, J.B., Smelror, M., Williams, G.L. Mesozoic - Tertiary dinoflagellates, acritarchs and prasinophytes. In Jansonius, J., and McGregor, D.C., (Eds.), Palynology: principles and applications. American Association of Stratigraphers and Palynologists Foundation, 2, 641 - 750, 1996.

[33] Oboh-Ikuenobe, F.E., Yepes, O., Gregg, J.M. Palynostratigraphy, Palynofacies, and Thermal Maturation of Cretaceous-Paleocene sediments from the Cote D'IvoireGhana Transform Margin. Proceedings for Ocean Drilling Programme Scientific Results, 159, 277-318, 1998.

[34] Costa, L.I., Davey, R.J. Dinoflagellate cysts from the Cretaceous System. In Powell, A. J., (Ed.), A stratigraphic index of Dinoflagellate cysts. British Micropaleontology Society Publication Service. Kluwer Academic Publishers, 99 - 154, 1999.

[35] Masure, E.,Rausher, R., Dejax, J., Schuler, M., Ferre, B. Cretaceous - Paleocene palynology from the Cote d'Ivoire Ghana transform margin, sites 959, 960, 961, and 962. In Mascle, J., Lohmann, G.P., Moullade, M., (Eds). Proceedings for Ocean Drilling Programme Scientific Results, 159, 253 276, 1998.

[36] Habib, D., Miller, J.A. Dinoflagellate species and organic facies evidence of marine trangression and regression in the Atlantic Coastal Plain. Paleogeography, Paleoclimatology and Paleoecology, 74, 23 - 47, 1989.

[37] Herngreen, G.F.W., Kedves, M., Rovnina, L.V., Smirnova, S.B Cretaceous palynofloral provinces a review. In Jansonius, J. \& McGregor, D.C. (Ed.), Palynology: Principles and applications, American Association of Stratigraphic Palynologists Foundation., 3, 1157-1188, 1996.

[38] Muller, J., de Di Giacomo, E., van Erve, A.W.A Palynological zonation for the Cretaceous, Tertiary and Quaternary of Northern South America. American Association of Stratigraphic Palynologists Contribution Series. 19, 7 - 76, 1987.

[39] Regali, M.S.P., Viana, C.F. Late Jurassic - Early Cretaceous in Brazilian sedimentary basins: correlation with the international standard scale. Petrobras, Rio de Janeiro, 95 pp., 1989.

[40] Jardiné, S., Magloire L. Palynologie et stratigraphie du Crétacé des bassins du Sénégal et Côte d'Ivoire. Memoire du Bureau Recherches de Geologique et Minières, 32, 187 - 245, 1965.

[41] Herngreen, G.F.W. Palynology of the Albian - Cenomanian strata of borehole 1 - QS - 1 - MA. State of Maranhao, Brazil. Pollen et Spores, 15, 515 - 555, 1973.
[42] Schrank, E. Palynology of the clastic Cretaceous sediments between Dongola and Wadi Muqaddam, Northern Sudan. Berliner Geowissenschaftliche Abhandlungen A, 120, 149 $168,1990$.

[43] Abubakar, M.B., Luterbacher, H.P., Ashraf, AR., Ziedner, R., Maigari, AS. Late Cretaceous palynostratigraphy in the Gongola Basin (Upper Benue Trough, Nigeria). Journal of African Earth Science, 60, 19-27, 2011.

[44] Doyle, J.A., Jardine, S., Doerenkamp, A. Afropollis a new genus of the early angiosperm pollen, with new notes on the Cretaceous palynostratigraphy and palaeoenvironmennts of northern Gondwana. Bulletin Centres de Recherche Exploration and Production, Elf Aquitaine, 6, (1), 39 - 117, 1982.

[45] Dino, R., Pocknall, D.T., Dettman, M.E. Morphology and ultrastructure of elater-bearing pollen from the Albian to Cenomanian of Brazil and Ecuador: implications for botanical affinity. Review of Palaeobotany and Palynology, 105, 201 235, 1999.

[46] Hunt, J.M. Petroleum Geochemistry and Geology. 2nd edition. Freeman, New York, 743 pp., 1996.

[47] Peters, K.E., Cassa, M.R. Applied source rock geochemistry. In: Magoon, L.B., Dow, W.G., (Eds.), The petroleum systemfrom source to trap, American Association of Petroleum Geologist. Memoir, 60, 93-120, 1994.

[48] Epstein, A.G., Epstein, J.B. and Harris, L.D. Conodont color alteration: an index to organic metamorphism: U.S. Geological Survey Professional Paper, 995, 27 pp. 1977.

[49] Espitalie J., Marquis, F., Barsony, I. Geochemical logging, In: Voorhees K.J. (ed) Analytical pyrolysis: techniques and applications. Butterworth, London, 276-304, 1984.

[50] Peters K.E. Guidelines for evaluating petroleum source rock using programmed pyrolysis: American Association of Petroleum Geologists Bulletin, 70, 318-329, 1986.

[51] Traverse, A. Paleopalynology, Unwin Hyman, Boston, 512 pp, 1988.

[52] Fowler, M., Snowdon, L., Stasiuk, V. Applying petroleum geochemistry to hydrocarbon exploration and exploitation. American Association of Petroleum Geologists Short Course Notes, June 18-19, Calgary, Alberta, 224 pp. 2005.

[53] Tissot, B.P., Welte, D.H. Petroleum Formation and Occurrence. (2nd Ed.), Springer-Verlag, Berlin, 699 pp. 1984.

[54] Obaje N.G., Wehner, H., Scheede G, Abubakar, M.B., Jauro, A Hydrocarbon prospectivity of Nigeria's inland basins: organic geochemistry and organic petrology, American Association of Petroleum Geologists Bulletin, 88, (3), 325 - 353. 2004.

[55] Tissot, B., Durand, B., Espitalié, J., and Combaz, A. Influence of the nature and diagenesis of organic matter in the formation of petroleum. American Association of Petroleum Geologists Bulletin, 58, 499-506. 1974.

[56] Espitalié, J., Laporte, L. J., Madec, M., Marquis, F., Leplat, P. J., Boutefeu, A. Méthode rapide de caractérisation des roches mères de leur potential petrolier et de leur degré devolution. Rev. Inst. Franc. Petrole, 32, 32-42, 1977.

[57] Peters, E., Joseph, S., Day, S., Garety, P. Measuring delusional ideation: the 21-item Peters et al. Delusions Inventory (PDI). Schizophrenia Bulletin, 30, 1005-1022, 2004. 
[58] Bacon D. J., Refregier A. R., Ellis R. S., MNRAS, 318, 625. , 2000. 